\title{
Phylogenetic Analysis of Entomoparasitic Nematodes, Potential Control Agents of Flea Populations in Natural Foci of Plague
}

\author{
E. I. Koshel, ${ }^{1}$ V. V. Aleshin, ${ }^{2,3,4}$ G. A. Eroshenko, ${ }^{1}$ and V. V. Kutyrev ${ }^{1}$ \\ ${ }^{1}$ Russian Research Anti-Plague Institute "Microbe", Saratov 410005, Russia \\ ${ }^{2}$ Belozersky Institute of Physical-Chemical Biology, Lomonosov Moscow State University, Moscow 119991, Russia \\ ${ }^{3}$ Institute for Information Transmission Problems, Russian Academy of Sciences, Moscow 127994, Russia \\ ${ }^{4}$ National Research Institute of Physiology, Biochemistry, and Nutrition of Farm Animals, Russian Academy of Agricultural Sciences, \\ Kaluga Region, Borovsk 249013, Russia
}

Correspondence should be addressed to E. I. Koshel; opossum39@mail.ru

Received 28 February 2013; Revised 5 June 2013; Accepted 22 October 2013; Published 3 April 2014

Academic Editor: Vassily Lyubetsky

Copyright (C) 2014 E. I. Koshel et al. This is an open access article distributed under the Creative Commons Attribution License, which permits unrestricted use, distribution, and reproduction in any medium, provided the original work is properly cited.

Entomoparasitic nematodes are natural control agents for many insect pests, including fleas that transmit Yersinia pestis, a causative agent of plague, in the natural foci of this extremely dangerous zoonosis. We examined the flea samples from the Volga-Ural natural focus of plague for their infestation with nematodes. Among the six flea species feeding on different rodent hosts (Citellus pygmaeus, Microtus socialis, and Allactaga major), the rate of infestation varied from 0 to 21\%. The propagation rate of parasitic nematodes in the haemocoel of infected fleas was very high; in some cases, we observed up to 1,000 juveniles per flea specimen. Our study of morphology, life cycle, and rDNA sequences of these parasites revealed that they belong to three distinct species differing in the host specificity. On SSU and LSU rRNA phylogenies, these species representing three genera (Rubzovinema, Psyllotylenchus, and Spilotylenchus), constitute a monophyletic group close to Allantonema and Parasitylenchus, the type genera of the families Allantonematidae and Parasitylenchidae (Nematoda: Tylenchida). We discuss the SSU-ITS1-5.8S-LSU rDNA phylogeny of the Tylenchida with a special emphasis on the suborder Hexatylina.

\section{Introduction}

More than 150 species of fleas feeding on different mammalian hosts, primarily rodents, are vectors of the bacterium Yersinia pestis, a causative agent of plague $[1,2]$. In natural foci of plague, the dynamics of flea populations are among the main factors controlling the incidence of epizootics that pose a threat to humans inhabiting the areas [3-5]. Entomoparasitic nematodes of the order Tylenchida are known to control populations of various insect hosts [6-9]. The rate of tylenchid infestation in fleas reaches $50-60 \%$ in some cases $[10,11]$, when the nematodes cause castration and early death of the flea hosts $[9,12,13]$.

Despite high importance of the Tylenchida as a nematode order harboring entomoparasites and notorious crop pests, their reliable phylogeny is still a challenge. Tylenchid nematodes differ widely in life cycle, parasitic strategies, and the host range that spans plants, fungi, and invertebrates.
Phylogenies obtained from SSU and partial LSU rDNA data often disagree with classifications based on morphology and life cycle [14-21]. Phylogenetic resolution inside the order is far from being clear, which in many respects results from the insufficiency of data available to adequately describe its diversity. As for tylenchid parasites of fleas, only 31 species are described to date $[9,22-31]$, with no molecular vouchering. Here we present a study of parasitic nematodes isolated from fleas sampled from different rodent hosts in a natural focus of plague.

\section{Materials and Methods}

2.1. Collection of Samples. Samples were collected in 2012 (spring and autumn) and 2013 (spring) in the Volga-Ural natural focus of plague (Figure 1). The sampled rodents included sousliks (Citellus pygmaeus), mouse-like rodents (Microtus socialis and Apodemus uralensis), and jerboas (Allactaga 


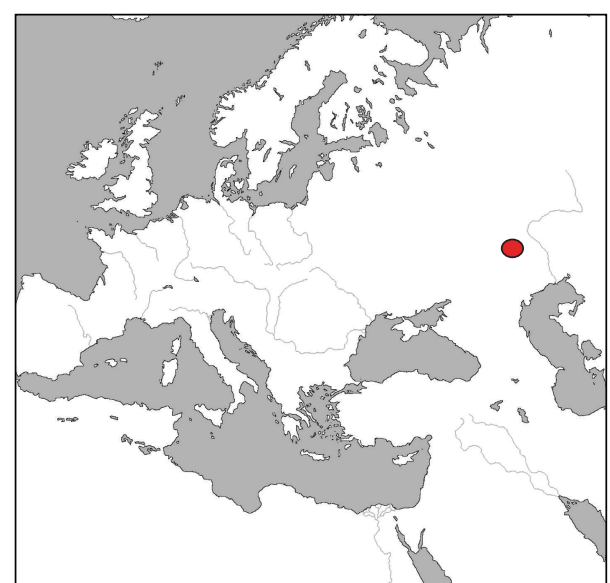

FIGURE 1: The sampling region on the map of Europe.

major). Three flea species (Citellophilus tesquorum, Neopsylla setosa, and Frontopsylla semura) were sampled on sousliks; two species (Amphipsylla rossica and Ctenophthalmus secundus) were on M. socialis voles; and one species (Mesopsylla hebes) was on jerboas. Fleas were examined for nematode infestation (Table 1). Examination and dissection of fleas were carried out using the dissecting microscope MBS-2 (LOMO, Russia). A half of parasitic nematodes sampled from each flea was preserved for subsequent DNA extraction, and another half was used for morphological analysis. Live fleas infected with nematodes were placed in glass flasks with river sand to obtain free-living forms. Insects were kept in a KBF 720 (E5.2) climate chamber (Binder, Germany) at $26^{\circ} \mathrm{C}$ and $80 \%$ humidity.

2.2. Morphological Analysis. Fixation and clarification of nematode preparations were performed using standard techniques described by De Grisse [32]. Material was mounted on slides in a drop of glycerin, bound by a paraffin circlet (http://pest.cabweb.org). Color staining of preparations was not performed. Morphometric analysis was conducted using the light microscope "Leica DM 1000" (Leica, Germany) with an eyepiece micrometer. Pictures of nematodes were taken with the microscope "DFC 425" (Leica, Germany). Published data on morphometrics $[23,25,26]$ were used for comparison.

2.3. DNA Extraction, PCR, and Sequencing. DNA samples were extracted with a Diatom DNA Prep (IsoGen Lab, Russia). rDNA fragments were amplified using an Encyclo PCR kit (Evrogen, Russia) and primers given in Table 2. The amplified rDNA fragments were sequenced using an Applied Biosystems 3500xL DNA analyzer. Sequence reads were assembled with the CAP contig assembly program [33] and proofread with the BioEdit software [34]. For three isolates, almost complete sequences of $18 \mathrm{~S}$ and $28 \mathrm{~S} \mathrm{rRNA}$ and complete sequences of 5.8 rRNA, internal transcribed spacers ITS1 and ITS2 were assembled. The sequences were submitted to GenBank under accession nos. KF155281-KF155283. For the rest of isolates, partial ( $750-800 \mathrm{bp}$ ) sequences of $18 \mathrm{~S}$ and
28S rRNA genes were submitted to GenBank under accession nos. KF373731-KF373740.

2.4. Phylogenetic Analysis. The newly obtained rDNA sequences of tylenchid parasites of fleas were aligned with a selected set of other tylenchid sequences obtained from the GenBank. The main selection criterion was to sample representatives of all clades that occur in published SSU and LSU rDNA phylogenies of the Tylenchida [16-21, 39]. Apart from the D2-D3 LSU rDNA expansion segment commonly used in previous studies, we included all LSU rDNA sequence data available for the Tylenchida, with the exception of Basiria sp. SAN-2005 (accession nos. DQ145619, DQ145667) that in our preliminary analyses (data not shown) demonstrated a disputable affinity to the Tylenchida. For the species Anguina tritici, Globodera pallida, Heterodera glycines, Pratylenchus vulnus, and Radopholus similes the nearly complete rDNA sequences were assembled with appropriate cDNA fragments identified with BLAST [40]. Partial LSU rDNA sequence of Ditylenchus dipsaci was combined with the soil environmental clone NTS_28S_061A_2_b4 (accession no. KC558346), as the clone sequence appeared to represent a close tylenchid relative of $D$. dipsaci. Chimeric sequences were also created in some cases when closely related partial rDNA sequences were found in the database. All sequences and their accession numbers are listed in Table 3. Cephalobidae and Chambersiellidae were chosen as the outgroup. Alignments were constructed with the MUSCLE program [41] and refined manually using the MEGA 5.0 software package [42]. Three alignments were generated: (1) SSU rDNA, (2) D3 region of LSU rDNA, and (3) concatenated rDNA data including SSU, LSU, 5.8S rDNA, and highly conserved regions of ITS1. After discarding ambiguously aligned positions, the alignments length was 1,723, 592, and 4,930 positions, respectively. Bayesian reconstruction of phylogeny was done with the PhyloBayes software, version 3.2 [43] under the GTR + CAT + DP model [44]. Eight independent runs were performed with 4,000,000 cycles each; the first 3,000,000 cycles were discarded. A consensus tree with Bayesian posterior probabilities was constructed for the remained tree sample. Bayesian reconstruction was also performed using the MrBayes software [45] under the GTR + G8 + I model [46] in two independent runs, each with four Markov chains. The chains were run for 5,000,000 generations, with trees sampling every 1,000th generation. The consensus posterior probabilities were calculated after discarding the first 3,000,000 generations. Partitioning "by genes" was used for the concatenated alignment with all parameters unlinked, except for the topology and branch lengths. In addition, node support was estimated with maximum likelihood bootstrap as implemented in the RAxML software, version 7.2.6 [47], under the GTR + G + I model with 1,000 bootstrap replicates. Alternative topologies were tested using the approximately unbiased (AU) [48] and Kishino and Hasegawa [49] tests implemented in the CONSEL software [50] and the expected likelihood weight test [51] implemented in the TREE-PUZZLE software [52]. TREEVIEW 
TABLE 1: Number of fleas studied and the percentage of fleas infected with nematodes.

\begin{tabular}{|c|c|c|c|c|c|}
\hline $\begin{array}{l}\text { Time of } \\
\text { sampling }\end{array}$ & $\begin{array}{l}\text { Host rodent } \\
\text { species }\end{array}$ & Flea species & $\begin{array}{l}\text { Number of } \\
\text { collected fleas }\end{array}$ & $\begin{array}{l}\text { Number of } \\
\text { infected fleas }\end{array}$ & $\begin{array}{l}\text { Percentage of infected } \\
\text { fleas }\end{array}$ \\
\hline \multirow{3}{*}{ April 2012} & \multirow{3}{*}{$\begin{array}{l}\text { Citellus } \\
\text { pygmaeus }\end{array}$} & Citellophilus tesquorum & 41 & 7 & $17.1 \%$ \\
\hline & & Neopsylla setosa & 73 & 5 & $6.8 \%$ \\
\hline & & Frontopsylla semura & 54 & 7 & $13 \%$ \\
\hline \multirow{2}{*}{ October 2012} & \multirow{2}{*}{ Microtus socialis } & Amphipsylla rossica & 135 & 9 & $6.7 \%$ \\
\hline & & Ctenophthalmus secundus & 88 & 1 & $1.1 \%$ \\
\hline \multirow{6}{*}{ April 2013} & \multirow{3}{*}{$\begin{array}{l}\text { Citellus } \\
\text { pygmaeus }\end{array}$} & Citellophilus tesquorum & 34 & 0 & 0 \\
\hline & & Neopsylla setosa & 271 & 22 & $8.1 \%$ \\
\hline & & Frontopsylla semura & 19 & 4 & $21 \%$ \\
\hline & \multirow{3}{*}{$\begin{array}{l}\text { Microtus socialis } \\
\text { and Apodemus } \\
\text { uralensis } \\
\text { Allactaga major }\end{array}$} & Amphipsylla rossica & 6 & 0 & 0 \\
\hline & & Ctenophthalmus secundus & 52 & 0 & 0 \\
\hline & & Mesopsylla hebes & 34 & 2 & $5.9 \%$ \\
\hline
\end{tabular}

TABLE 2: Nucleotide sequences of primers used in this study.

\begin{tabular}{|c|c|c|c|}
\hline Primer & Sequence & Orientation & References \\
\hline Nik22 & tmycygrttgatyctgyc & $\mathrm{F}$ & This study \\
\hline A & gtatctggttgatcctgccagt & $\mathrm{F}$ & [35] \\
\hline Q5nemCh & gccgcgaayggctcattayaac & $\mathrm{F}$ & This study \\
\hline G18SU & gcttgtctcaaagattaagcc & $\mathrm{F}$ & [36] \\
\hline Ves18-d9 & gtcgtaacaaggtatccgtaggtgaac & $\mathrm{F}$ & This study \\
\hline R18Tyl1 & ggtccaagaatttcacctctc & $\mathrm{R}$ & [36] \\
\hline $\mathrm{B}$ & gtaggtgaacctgcagaaggatca & $\mathrm{R}$ & [35] \\
\hline Q39nem & gaaaccttgttacgacttttrcbygg & $\mathrm{R}$ & This study \\
\hline $58 \mathrm{~d} 1$ & rcatcgatgaagaacgywg & $\mathrm{F}$ & [37] \\
\hline 58r nem & gcwgcgttcttcatcgacyc & $\mathrm{R}$ & This study \\
\hline $28 \mathrm{~d} 3$ & gtcttgaaacacggaccaagg & $\mathrm{F}$ & [37] \\
\hline $28 \mathrm{~d} 6$ & ggtyagtcgrtcctrag & $\mathrm{F}$ & [37] \\
\hline $\mathrm{D} 2 \mathrm{~A}$ & acaagtaccgtgagggaaagttg & $\mathrm{F}$ & {$[38]$} \\
\hline $28 \mathrm{r} 4$ & gctatcctgagggaaacttcgg & $\mathrm{R}$ & {$[37]$} \\
\hline 28r2nem & cggtacttgttcgctatcg & $\mathrm{R}$ & This study \\
\hline $28 \mathrm{r} 7$ & agccaatccttwtcccgaagttac & $\mathrm{R}$ & [37] \\
\hline $28 \mathrm{r} 12$ & ttctgacttagaggcgttcag & $\mathrm{R}$ & {$[37]$} \\
\hline D3B & tcggaaggaaccagctacta & $\mathrm{R}$ & {$[38]$} \\
\hline
\end{tabular}

[53] was used as the tree viewer and editor, and site-wise loglikelihoods were computed with TREE-PUZZLE under the $\mathrm{GTR}+\mathrm{G} 8$ + I model with substitution matrix parameters estimated by MrBayes.

\section{Results}

3.1. Infestation of Fleas with Nematodes. The infestation rate is shown in Table 1 (in total, 807 flea specimens were studied). Among the six flea species studied, the population size and the percentage of infected fleas varied depending on the season. Three flea species sampled on sousliks (Citellophilus tesquorum, Neopsylla setosa, and Frontopsylla semura) exhibited a stable population density. In the two species, $N$. setosa and F. semura, the infestation rate was moderate to high in the spring seasons of 2012 and 2013. In C. tesquorum, no infected fleas were detected in spring 2013, whereas in spring 2012 the fleas were highly infested (17.1\%). The vole flea Amphipsylla rossica was abundant and moderately infested in autumn, whereas being less abundant in spring, which may explain the absence of infected fleas in the spring sample. Another vole flea, Ctenophthalmus secundus, exhibited a consistently high population density and low infestation rate in both spring and autumn samples.

Adult parasitic females and their progeny were found in the haemocoel of infected fleas. In the infected fleas $C$. tesquorum, A. rossica, C. secundus, and Mesopsylla hebes, only one generation of parasitic females was observed. Their amount in a flea specimen is determined by the number of free-living infective females that penetrate into the flea larva. We observed 1 to 2 or 1 to 4 adult parasitic females per flea specimen in spring and autumn, respectively. An additional parthenogenetic generation of parasitic females was found in some fleas of $N$. setosa and F. semura, where 


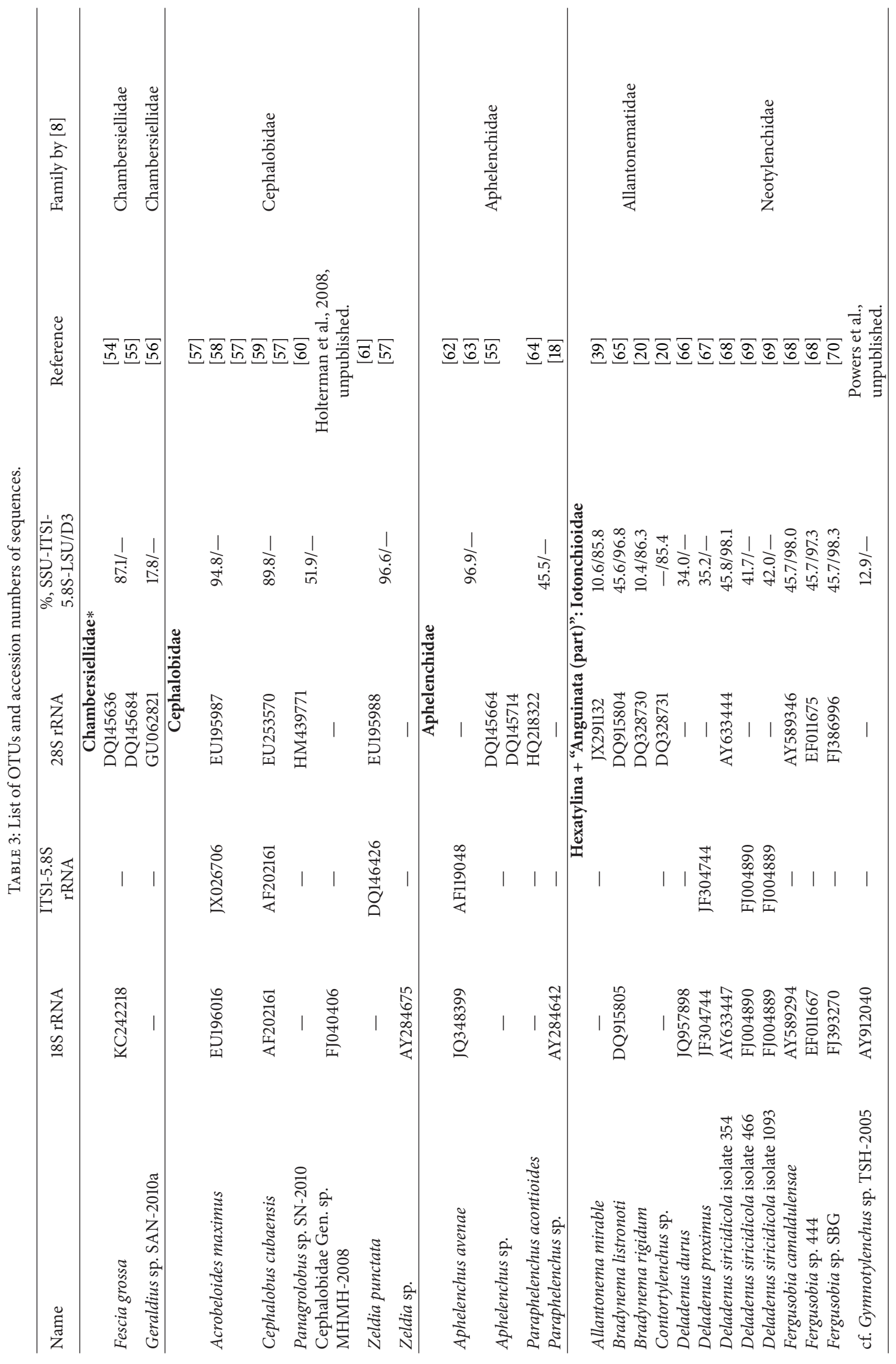




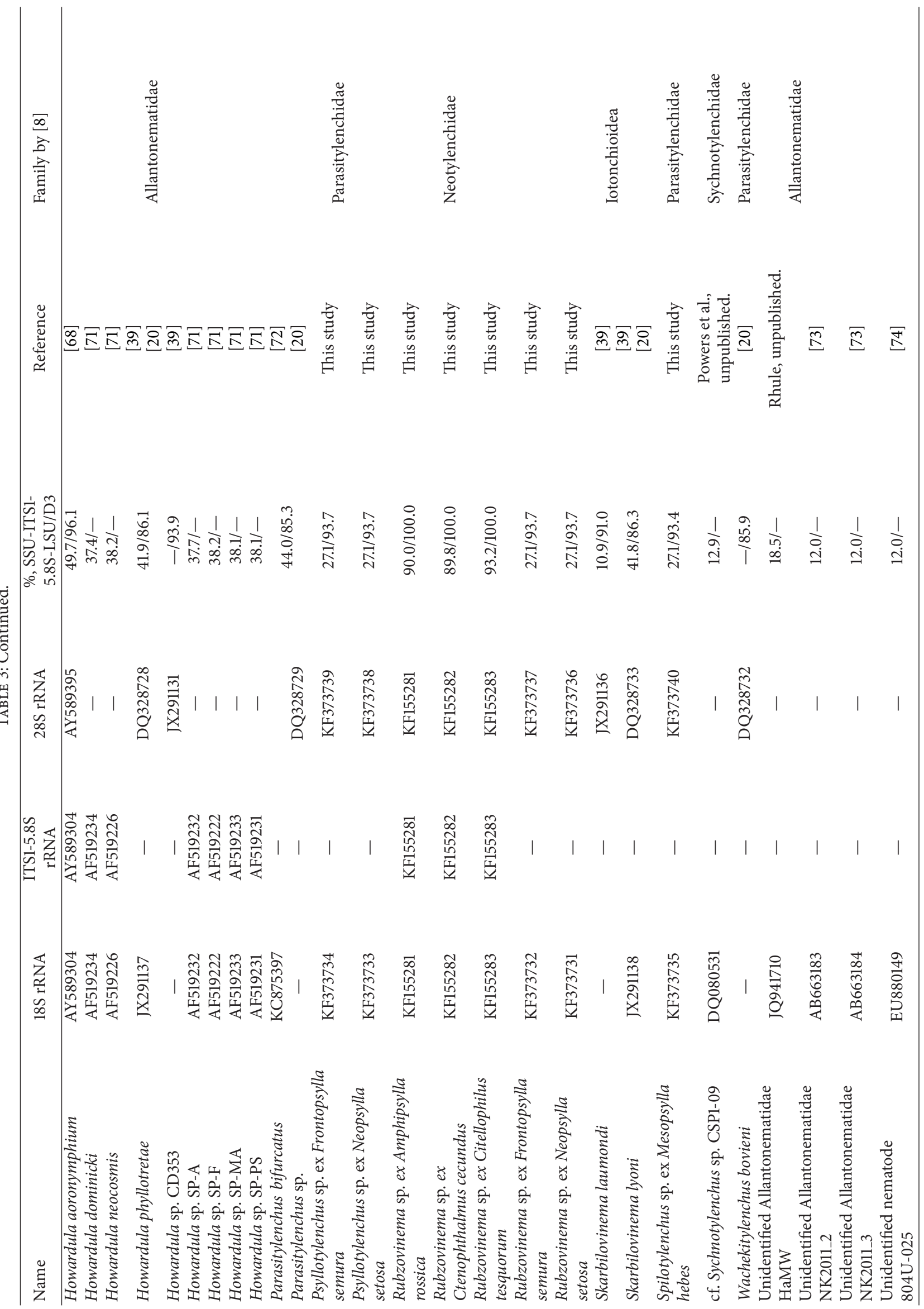




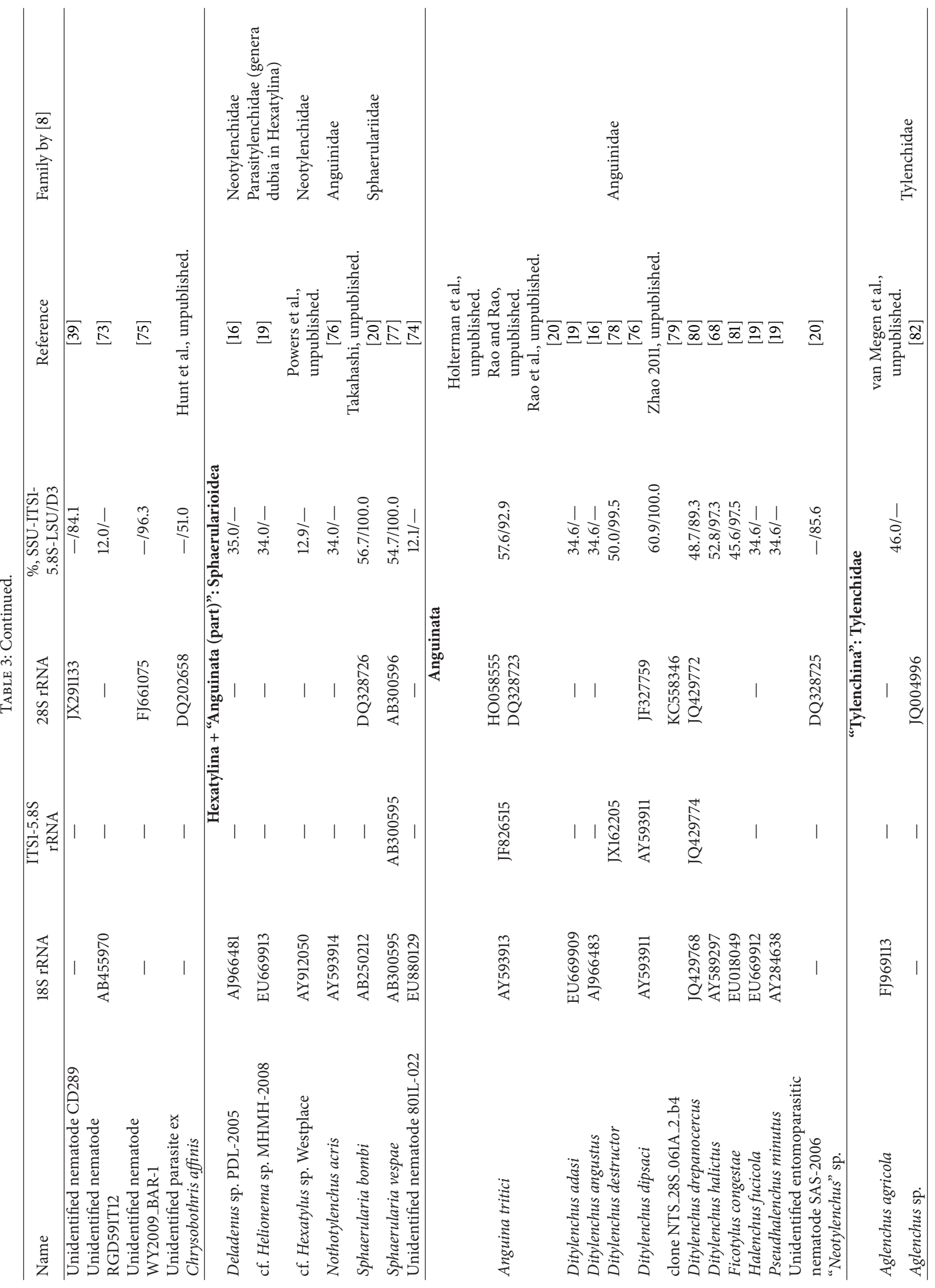




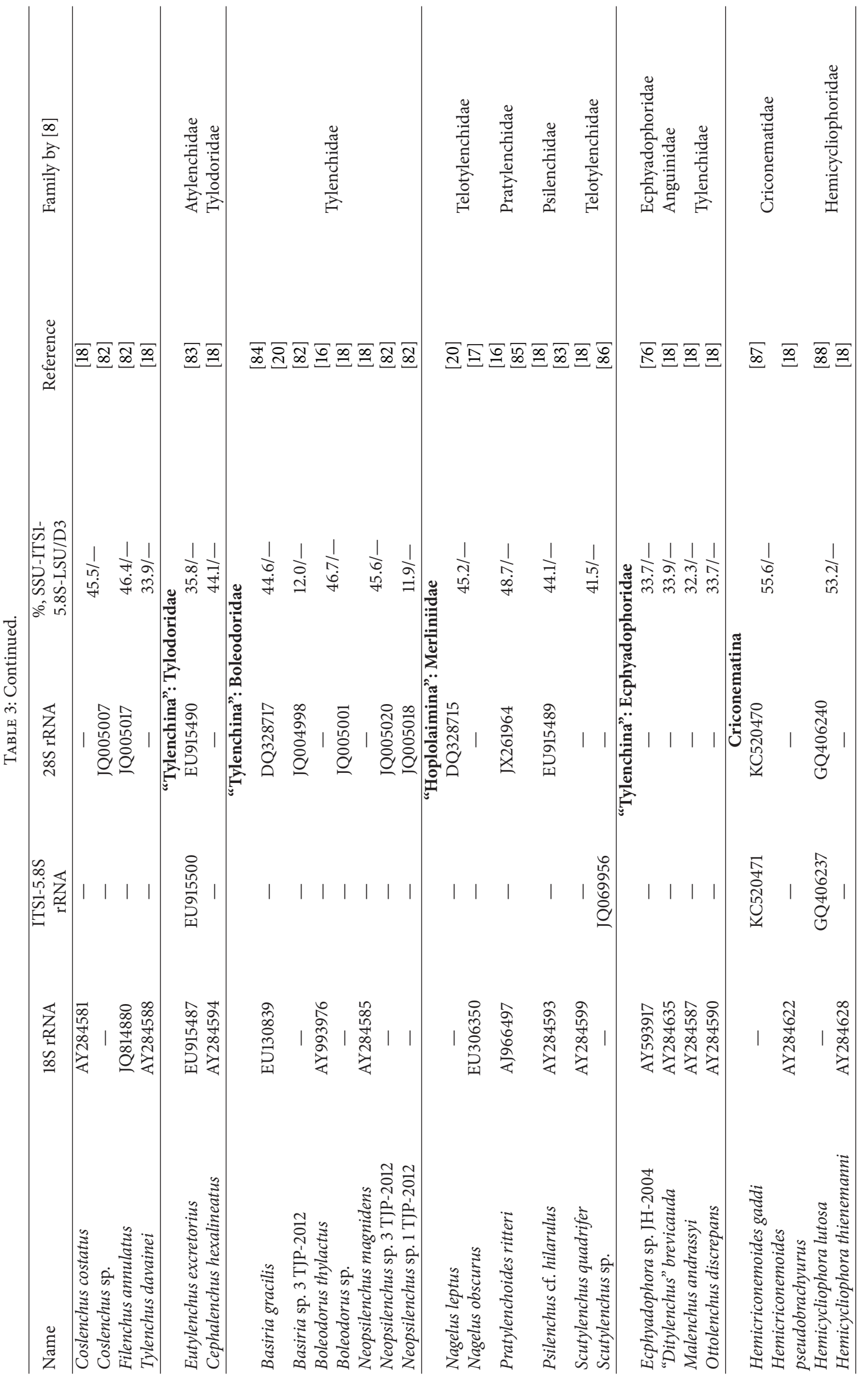




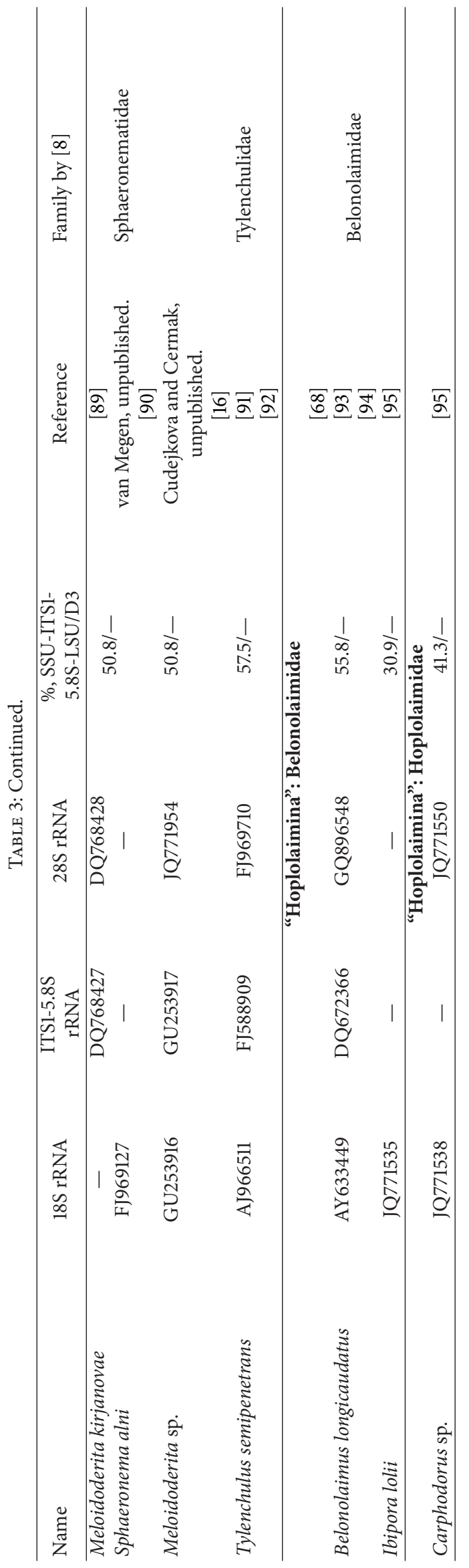




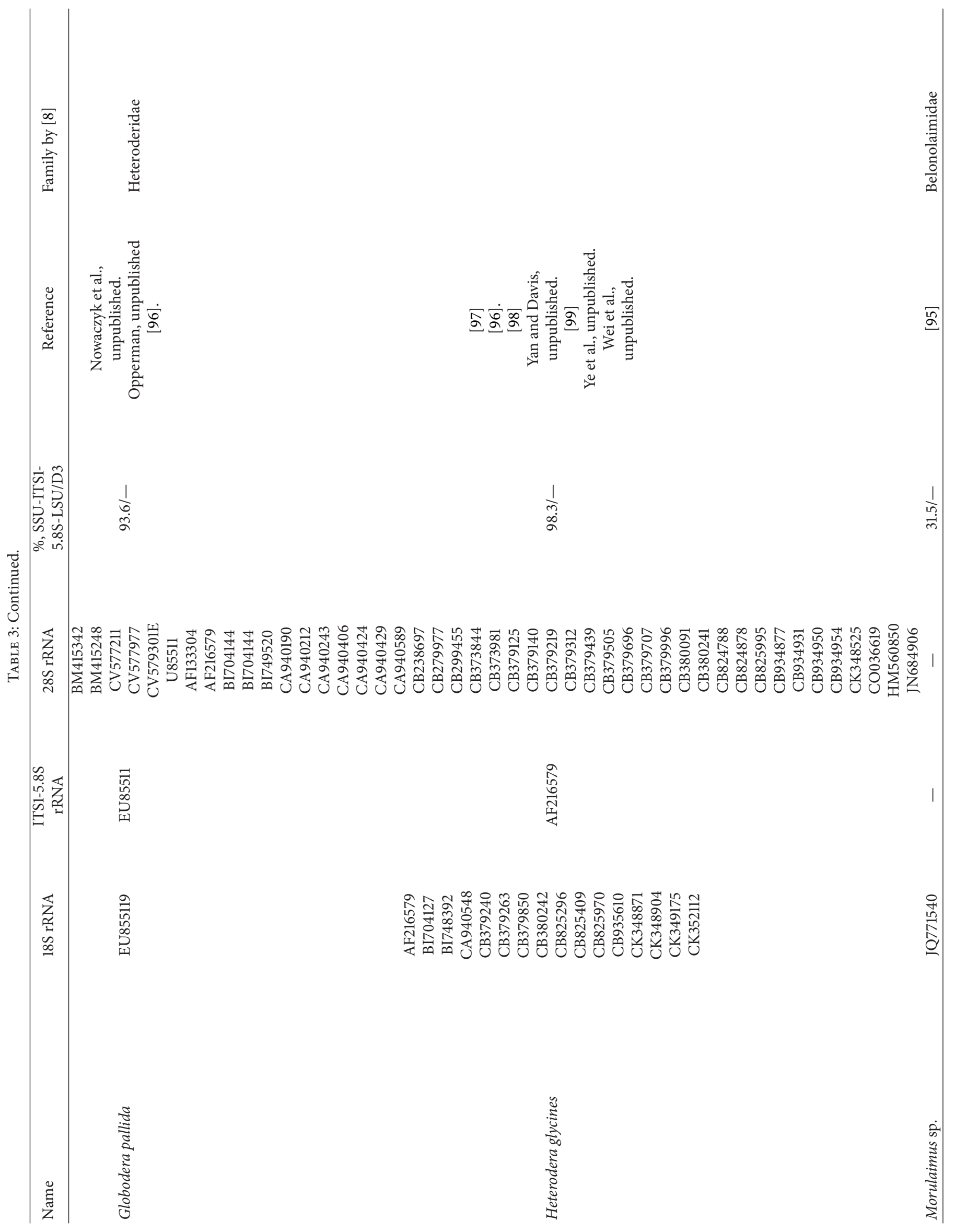




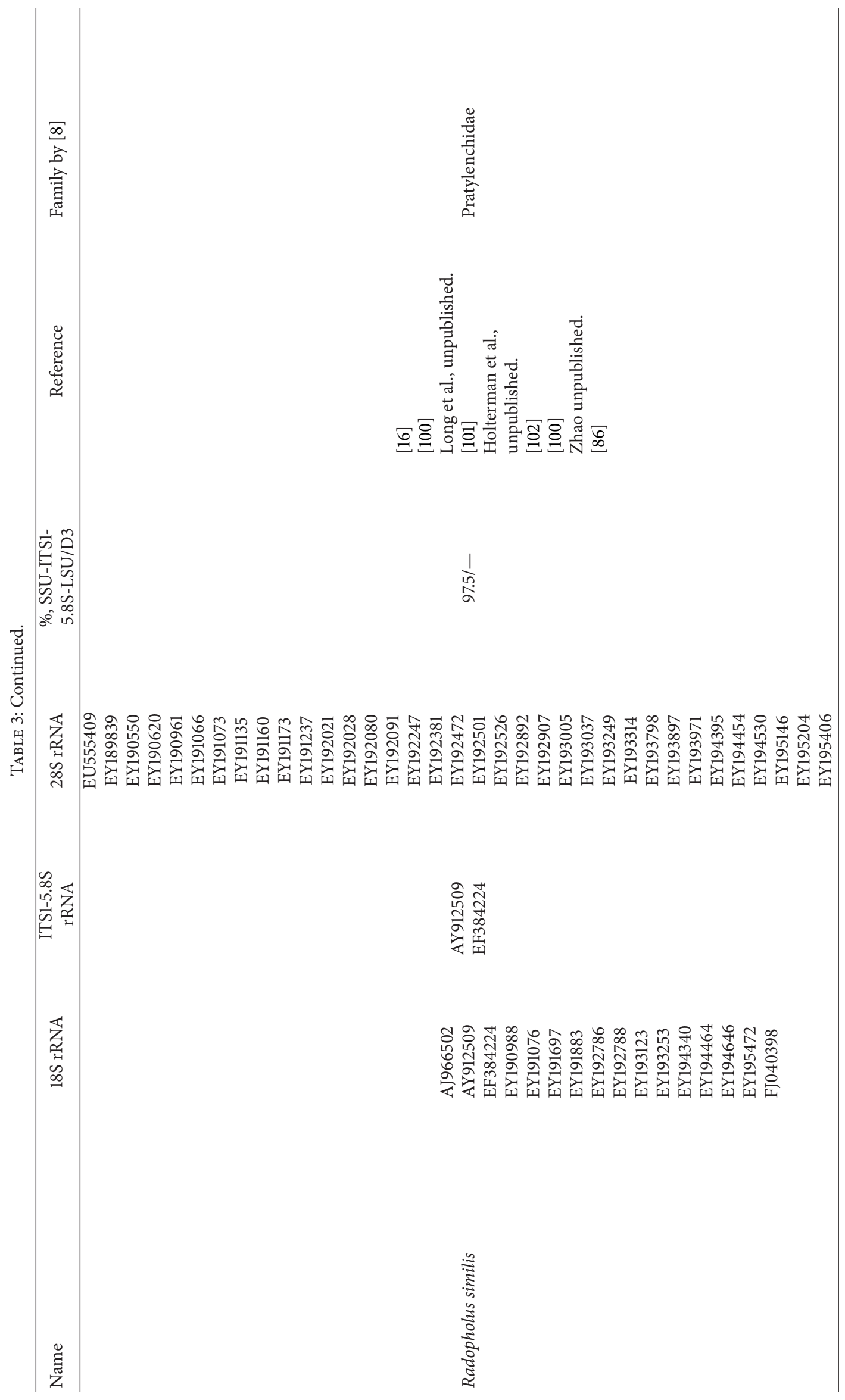




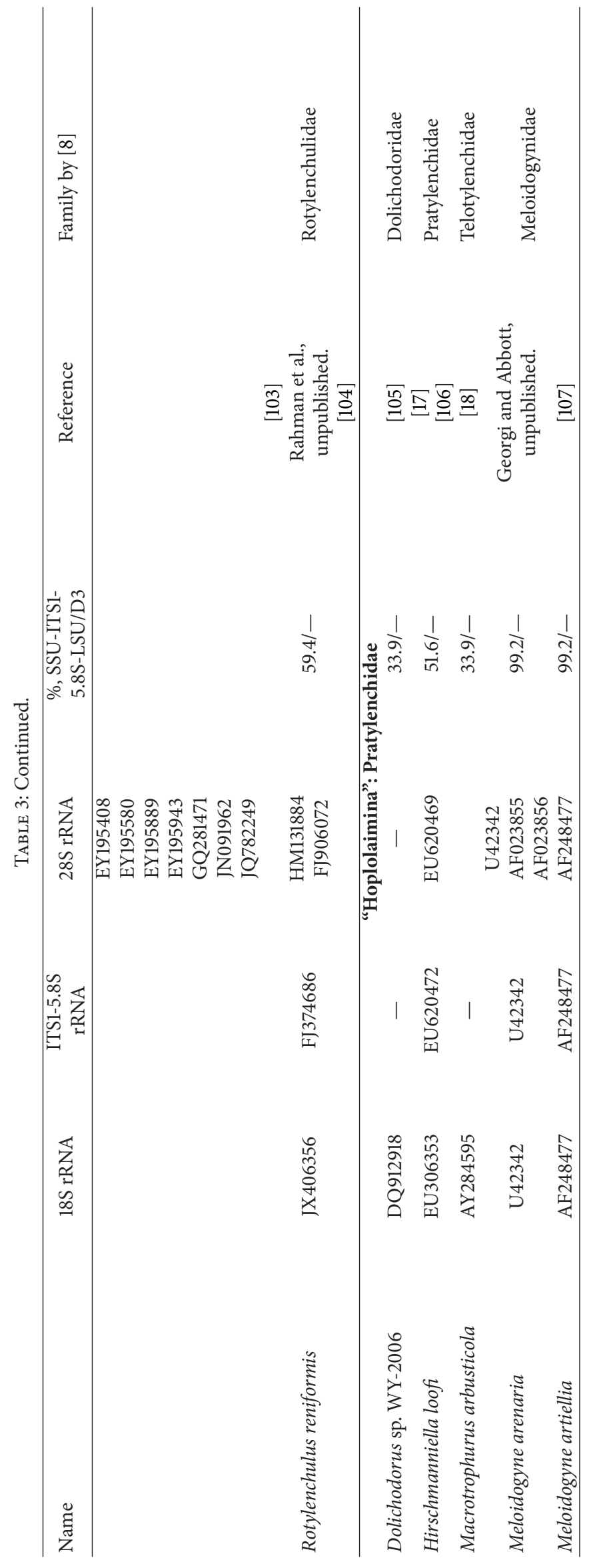




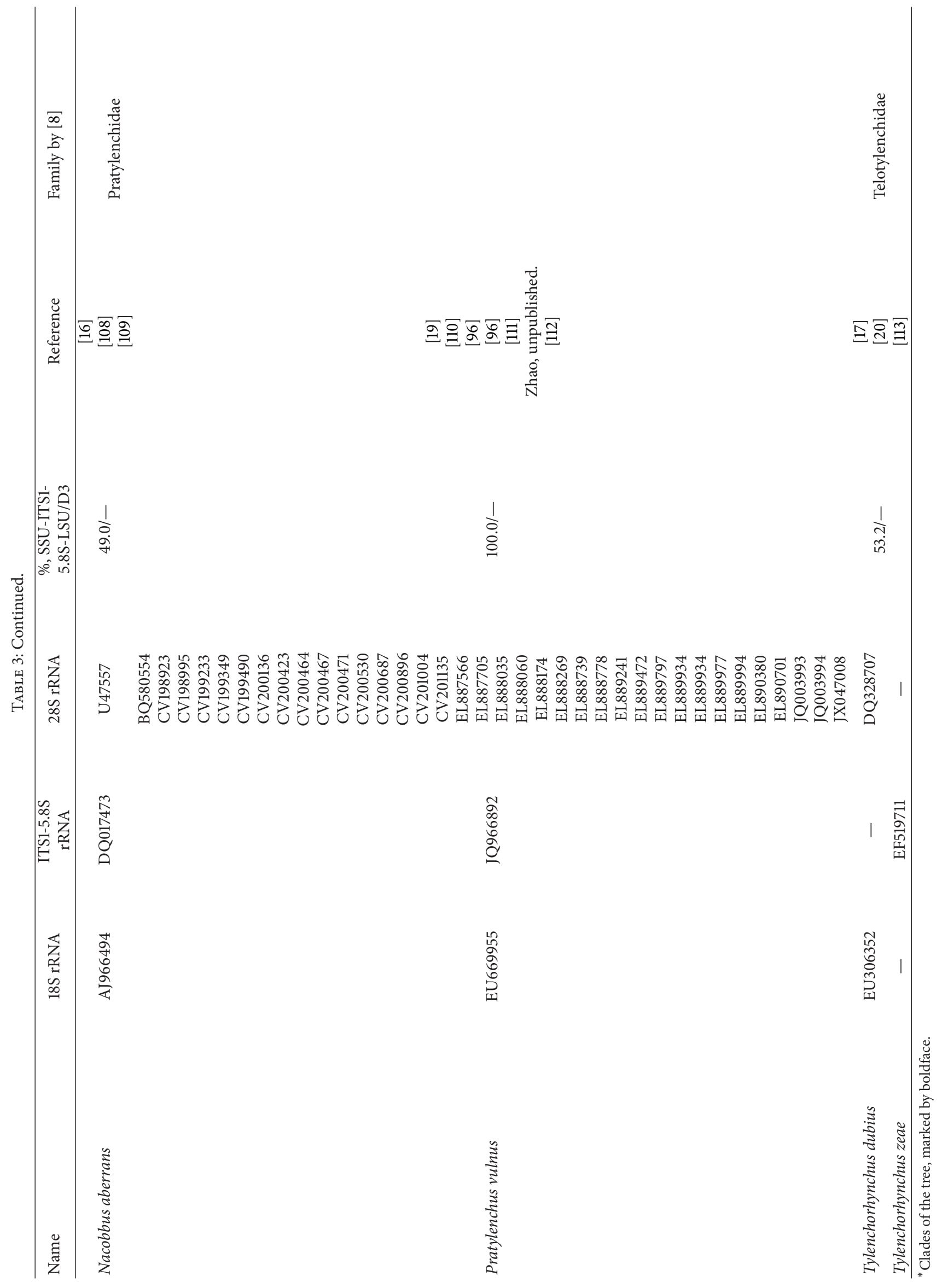




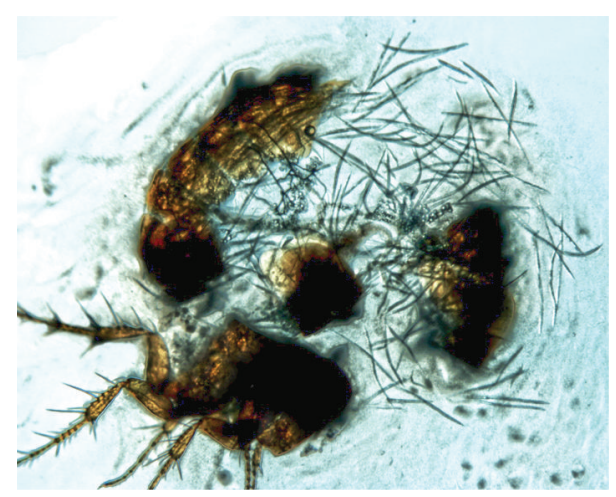

Figure 2: Numerous juveniles of Rubzovinema sp. extracted from the dissected body of a Citellophilus tesquorum flea.

up to 16 specimens per flea were observed. As in other entomoparasitic nematodes, the propagation rate depends on the host age. Thus, in young fleas up to 10 juveniles was found per flea specimen, whereas up to 1,000 juveniles of different stages were contained in some old fleas (Figure 2). After the 2 nd molt the number of juveniles is maximal, and 3rd stage juveniles massively migrate to the rectal section of the flea intestine for exit to the environment. In some cases, the observed infestation level was so high that nematodes penetrated distal segments of the flea legs, from where they have no way to the environment.

3.2. Morphological Analysis of Entomoparasitic Stages in Nematode Isolates and Their Taxonomic Identification. Analysis of morphology of entomoparasitic stages suggests that the studied nematode isolates from three distinct groups. A single generation of parasitic females was observed in the first two groups and an additional parthenogenetic generation-in the third group. According to morphometric data on adult parasitic females (Tables 4-6), the first two groups belong to the genera Rubzovinema or Spilotylenchus and the third group to the genus Psyllotylenchus. Photographs of parasitic females of Rubzovinema sp., Spilotylenchus sp., and Psyllotylenchus sp. are depicted in Figure 3. Figure 4 shows their distribution among flea samples studied.

According to morphometric evidence, parasitic females and juveniles of the genera Rubzovinema and Spilotylenchus are very similar. However, in the first two groups of isolates we found characters bearing discriminative and identificational value. In particular, the oesophageal glands in juveniles III of the first group are poorly developed. This is a distinctive feature of the genus Rubzovinema, where males and females have shortened oesophageal glands located close to the nerve ring. In the second group of isolates, oesophageal glands are well developed and elongated, which is characteristic of the genus Spilotylenchus. In the first group, the stylet possesses a heavily sclerotized distal spear with a length of approximately half the total stylet length and has a stem with a weaker sclerotization and widening to the base. This stylet structure is characteristic of the genus Rubzovinema, and stylet length (18.5 (14-22) $\mu \mathrm{m})$ is in accordance with morphometrics given in the description of this genus [26]. In the genus Spilotylenchus, the stylet varies in shape but always possesses a shortened conical distal spear. In the second group of isolates, the stylet structure was similar to that of Spilotylenchus. Also, the vulval lips of the first group are more protruded than in Spilotylenchus. Other features, including the morphometrics, vary widely in both genera, which hampers taxonomic identification. Nevertheless, based on distinctive traits, we identified the first and second group of isolates as Rubzovinema sp. and Spilotylenchus sp., respectively.

In the genus Rubzovinema, the single species described to date is Rubzovinema ceratophylla [26]. This species is known to parasitize exclusively the flea Citellophilus tesquorum that feeds on sousliks. The specimens of Rubzovinema studied in this work were isolated from five flea species, C. tesquorum, Neopsylla setosa, Frontopsylla semura, Amphipsylla rossica, and Ctenophthalmus secundus, of which the latter two were sampled on mouse-like rodents. Also, the parasitic females of Rubzovinema sp. differed from $R$. ceratophylla by morphology; they have a shorter tail and more protruded vulval lips. A morphometric comparison of Rubzovinema sp. and $R$. ceratophylla is given in Table 4.

The parasitic females of Spilotylenchus sp. were isolated from the flea Mesopsylla hebes associated with jerboas. The females were not identified to the species level because of a small number of available specimens and the lack of a freeliving stage. A morphometric comparison of Spilotylenchus sp. and the morphologically closest species Spilotylenchus maisonabei [23] is given in Table 5.

In the genus Psyllotylenchus, descriptions of most species are fragmentary and incomplete, which precluded the species identification of the Psyllotylenchus isolates from the fleas $N$. setosa and F. semura feeding on sousliks. A morphometric comparison of Psyllotylenchus sp. and the type species of this genus, Psyllotylenchus viviparous [25], is given in Table 6.

The $18 \mathrm{~S}$ and $28 \mathrm{~S}$ rDNA sequences of Rubzovinema sp. specimens from A. rossica and C. secundus were $100 \%$ identical, which indicates that the isolates belong to the same species. The sequences of Rubzovinema sp. ex C. tesquorum, Rubzovinema sp. ex N. setosa, and Rubzovinema sp. ex F. semura diverged from one another and from the gene sequences of Rubzovinema sp. ex A. rossica and Rubzovinema sp. ex C. secundus by $0.4-0.7 \%$, which corresponds to the levels of intraspecific variation [14, 114-119]. The $18 \mathrm{~S}$ and 28S rDNA sequences of Psyllotylenchus sp. ex N. setosa and Psyllotylenchus sp. ex F. semura were $100 \%$ identical, indicating that they belong to the same species. The $18 \mathrm{~S}$ and $28 \mathrm{~S}$ rDNA sequences of Rubzovinema sp. and Psyllotylenchus sp. diverge by $1.2 \%$ and $1.9 \%$, respectively. Those of Spilotylenchus sp. ex $M$. hebes were found to be more divergent. The degree of divergence of the $18 \mathrm{~S}$ rDNA sequence of Spilotylenchus sp. ex M. hebes from those of either Rubzovinema sp. or Psyllotylenchus sp. was 2.4\%; the D3 expansion segment of $28 \mathrm{~S}$ rDNA diverged by $13.1 \%$ and $12.0 \%$, respectively. The observed divergence rate of rDNA sequences agrees well with published evidence on entomoparasitic nematodes $[14,114-118]$. Thus, intraspecific divergence of $18 \mathrm{~S}$ rDNA in Deladenus siricidicola is 1\% [120], of D2 and D3 expansion segments in the phytoparasite Bursaphelenchus xylophilus is from $0 \%$ to $0.6 \%$, and the interspecific variation between the 


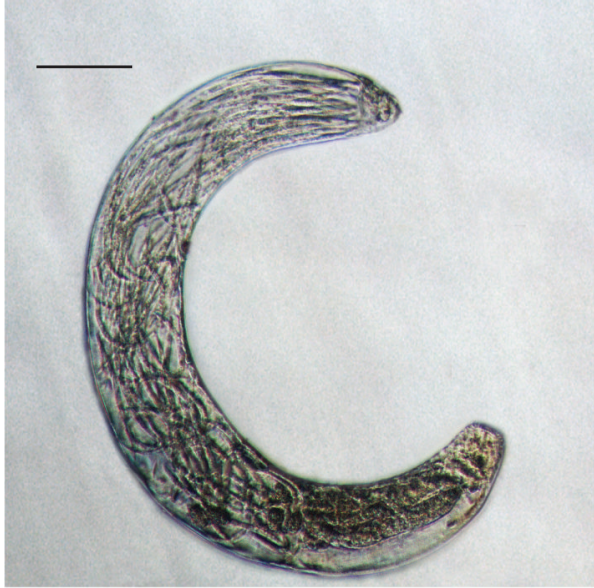

(a)

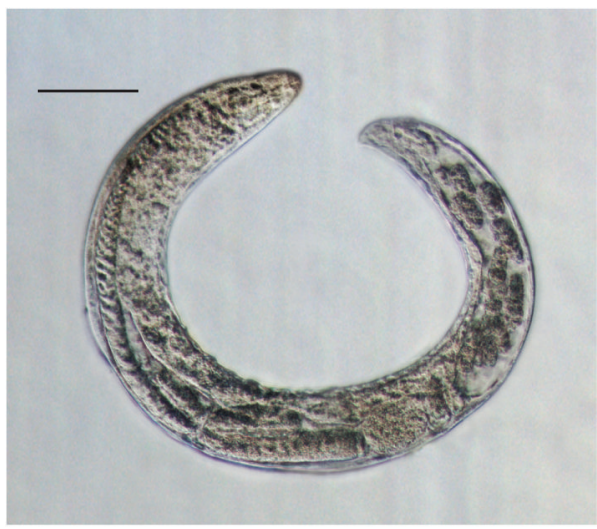

(c)

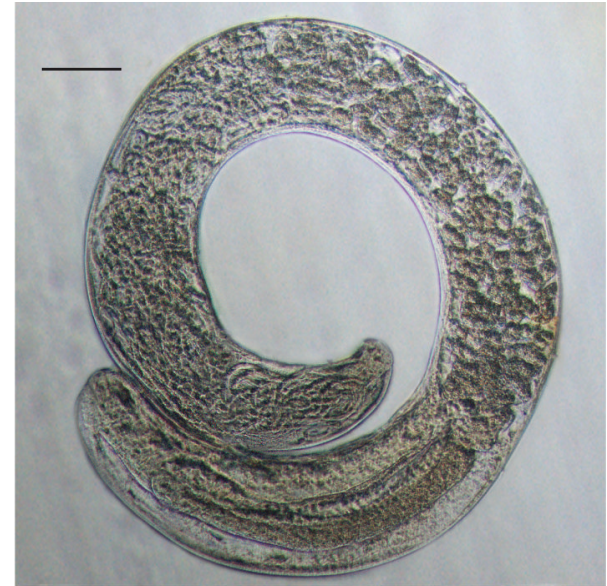

(b)

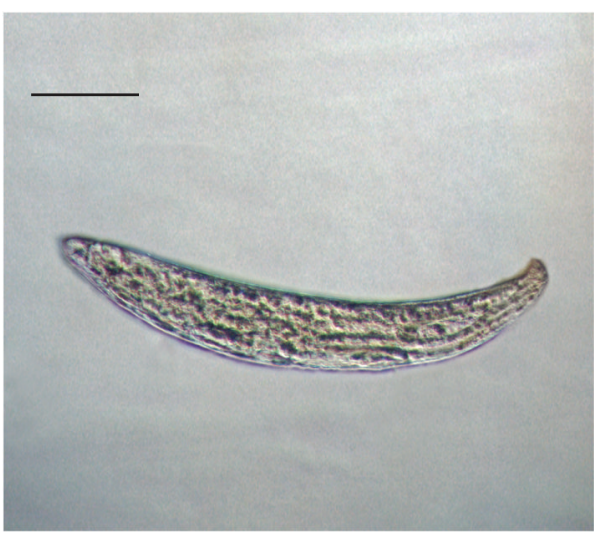

(d)

Figure 3: Parasitic females of the studied nematode species. (a) Rubzovinema sp., heterogeneous female; (b) Spilotylenchus sp., heterogeneous female; (c) Psillotylenchus sp., heterogeneous female of the first generation; (d) (c): Psillotylenchus sp., parthenogenetic female of the second generation. Scale bar-200 $\mu \mathrm{m}$.

TABLE 4: Comparison of morphometrics in parasitic females of Rubzovinema sp. and Rubzovinema ceratophylla.

\begin{tabular}{lcc}
\hline Character & Rubzovinema sp. (this study) & Rubzovinema ceratophylla [26] \\
\hline $\mathrm{N}$ & 29 & 27 \\
$\mathrm{~L}$ & $1278,6(840-1570)$ & $1265,1(810-1840)$ \\
$\mathrm{D}$ & $120,8(85-145)$ & $137,3(62-200)$ \\
$\mathrm{A}$ & $11,19(7,9-16,1)$ & $9,51(6,4-16,8)$ \\
$\mathrm{C}$ & $65,4(31,4-100)$ & $44,10(10-86,4)$ \\
V\% & $96,4(93,1-97,9)$ & $95,44(92-98,9)$ \\
Total length of stylet (St) & $18,5(14-22)$ & $19,5(18-21)$ \\
Length of distal edge of stylet & $7,2(5-8,7)$ & - \\
Distance between anterior end and excretory pore (Ex) & $20,7(10-31)$ & - \\
Distance between anterior end and nerve ring & $61,2(50-74,5)$ & \\
Total length of tail (Cd) & $21,9(10-42)$ & - \\
Distance between vulva and tail end & $46,1(23-75)$ & - \\
Distance between vulva and anus (V-A) & $26,9(13-40)$ & - \\
\hline
\end{tabular}

All measurements are in $\mu \mathrm{m}$ and in the form mean (range). 
TABLE 5: Comparison of morphometrics of parasitic females in Spilotylenchus sp. and Spilotylenchus maisonabei.

\begin{tabular}{lcc}
\hline Characters & Spilotylenchus sp. (this study) & Spilotylenchus maisonabei [23] \\
\hline $\mathrm{N}$ & 2 & 6 \\
$\mathrm{~L}$ & $1,600-1,840$ & $1,244(1,200-1,320)$ \\
$\mathrm{D}$ & $155-160$ & $125(107-160)$ \\
$\mathrm{A}$ & $10.3-11.5$ & $10.3(7.5-12)$ \\
$\mathrm{C}$ & $167.3-177.8$ & $84.4(64.5-121)$ \\
V\% & $97.4-97.7$ & $96.2(95.8-96.5)$ \\
Total length of stylet (St) & $9.5-9.8$ & $9-10$ \\
Distance between anterior end and excretory pore & $1.5-15.5$ & $23.3(20-28)$ \\
Distance between anterior end and nerve ring & - & $52-54$ \\
Total length of tail (Cd) & $9-11$ & $15.4(10-19)$ \\
Distance between vulva and tail end & $41.5-43$ & $47(42-52)$ \\
Distance between vulva and anus (V-A) & $32-33$ & - \\
\hline
\end{tabular}

All measurements are in $\mu \mathrm{m}$ and in the form mean (range).

TABLE 6: Comparison of morphometrics of parasitic females in Psyllotylenchus sp. and Psyllotylenchus viviparous.

\begin{tabular}{|c|c|c|c|c|}
\hline \multirow{2}{*}{ Character } & \multicolumn{2}{|c|}{ Psyllotylenchus sp. (this study) } & \multicolumn{2}{|c|}{ Psyllotylenchus viviparous [25] } \\
\hline & Gamogenetic & Parthenogenetic & Gamogenetic & Parthenogenetic \\
\hline $\mathrm{N}$ & 3 & 7 & 8 & 10 \\
\hline $\mathrm{L}$ & $1,016.7(900-1,100)$ & $446(420-500)$ & $1,000(840-1,480)$ & $500(360-840)$ \\
\hline $\mathrm{D}$ & $81.3(79-84)$ & $70(60-80)$ & $77(62-115)$ & $60(54-100)$ \\
\hline A & $12.5(11.1-13.3)$ & $6.25(5.6-7)$ & - & - \\
\hline $\mathrm{C}$ & $64.3(60-68.2)$ & $40.15(37.1-43.5)$ & - & - \\
\hline $\mathrm{V} \%$ & $95.1(95-95.4)$ & $93.3(90-95.3)$ & - & - \\
\hline Total length of stylet (St) & $17.5(17-18,5)$ & $5.25(4-6)$ & $17(15-20)$ & $7(5-8)$ \\
\hline Length of the distal edge of stylet & $8.6(8-9)$ & - & - & - \\
\hline Distance between anterior end and excretory pore & $26.5(25-31.5)$ & $17.5(15-19.5)$ & $23(13-33)$ & $22(14-46)$ \\
\hline Distance between anterior end and nerve ring & - & $51.7(50-55)$ & - & - \\
\hline Total length of tail $(\mathrm{Cd})$ & $15.8(15-17)$ & $11.1(10.5-11.5)$ & $25(17-35)$ & $9(1-17)$ \\
\hline Distance between vulva and tail end & $48(45-51)$ & $30.5(19.7-55)$ & $56(37-71)$ & $52(40-104)$ \\
\hline Distance between vulva and anus $(\mathrm{V}-\mathrm{A})$ & $30.8(29-31.5)$ & $13.5(11.7-21.6)$ & - & - \\
\hline
\end{tabular}

All measurements are in $\mu \mathrm{m}$ and in the form mean (range).

phytoparasites B. xylophilus and Bursaphelenchus mucronatus is from $1.7 \%$ to $3.7 \%$. The spacers ITS1 and ITS2 are generally more diverged; the intra- and interspecific variation for these species is from 0 to $3.1 \%$ and 11.2 to $13.4 \%$, respectively [121123].

Molecular vouchering is proved to efficiently complement morphological species identification in nematodes $[73,122$, 124-128]. Combining the rDNA and morphological data confirms the species identity within each of the three studied groups of isolates.

3.3. Phylogenetic Analysis. In phylogenetic analyses of rDNA we used a dataset with extensive species and gene sampling (SSU-ITS1-5.8S-LSU) compared to earlier published tylenchid phylogenies, most of which were based on SSU rDNA or D2-D3 expansion segments [17, 19-21, 39, 129]. The SSU-ITS1-5.8S-LSU rDNA tree topology (Figure 5) is highly similar to other published phylogenies of tylenchids. In this tree, tylenchomorphs are represented by the sister groups Aphelenchidae and Tylenchida. Most of the tylenchid clades occur in published trees but often contradict classifications based on morphology, as it was also noted by other authors [17, 19-21, 39, 129]. The three robust major branches in the SSU-ITS1-5.8S-LSU rDNA tree (Bayesian posterior probabilities of $0.99-1.0)$ are (1) the clade includes representatives of the suborders Hoplolaimina, Criconematina, and Tylenchina (excluding Anguinoidea); (2) the majority of classic Anguinata; (3) the suborder Hexatylina. The studied parasites of fleas form a monophyletic group (bootstrap support of $100 \%$ ) within the Hexatylina.

The nonredundant rDNA data on the Hexatylina in GenBank mostly represents the D2-D3 expansion segments of LSU rDNA. To maximize species sampling of the Hexatylina, we chose the D3 expansion segment as the molecular marker. The phylogenetic tree with the Anguinoidea as an outgroup is shown in Figure 6. In this tree, the suborder Hexatylina consists of two well-supported clades, in accordance with previously published D2-D3 rDNA phylogenies [19, 20, 39]. The clade of the studied flea parasites is placed within the 


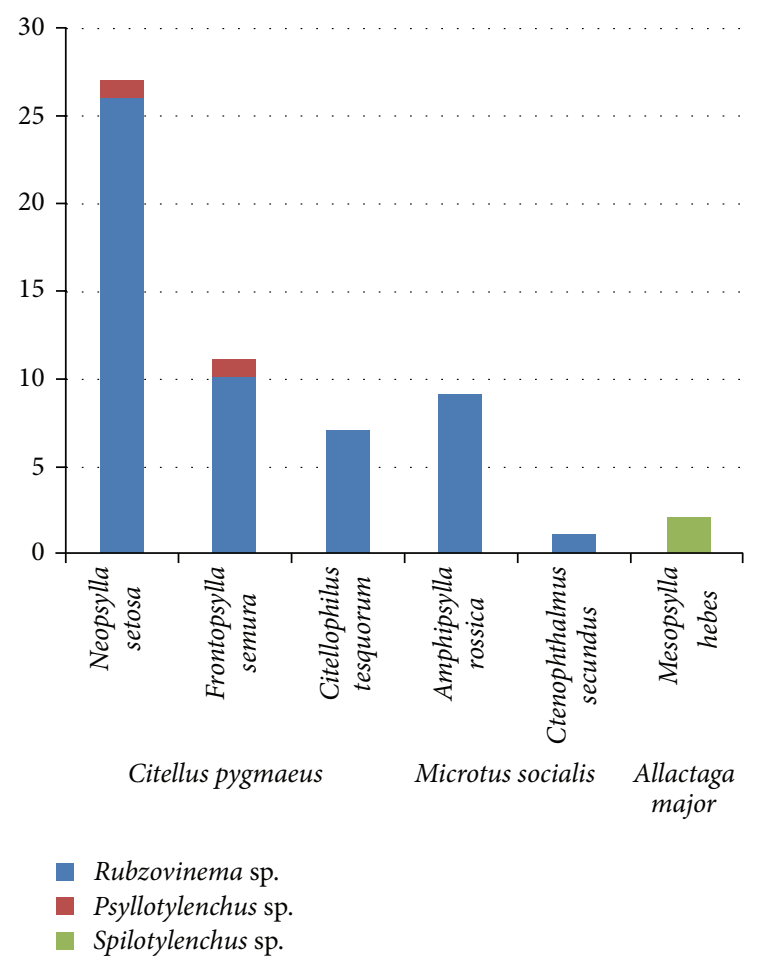

FIGURE 4: Distribution of the studied nematode species among the flea species studied, whose rodent hosts are given below. The vertical axis shows the numbers of infected fleas.

largest branch of the Hexatylina, similarly to the result of the concatenated rDNA analysis.

The three alternative relationships between the three major branches of Tylenchida (Figure 5) are not discriminated by the $\mathrm{AU}$ and Kishino and Hasegawa tests, and only the basal position of the Hexatylina is rejected by the expected-likelihood weights test (Table 7). All three tests do not discriminate between the alternative placement of the flea parasites as closest to the Allantonema, Parasitylenchus, or Deladenus branches; however, its positioning outside this grouping is not rejected only by a less conservative Shimodaira-Hasegawa test [50].

\section{Discussion}

4.1. Ribosomal DNA Phylogeny of the Tylenchida and Relationships within the Suborder Hexatylina. Phylogenetic analyses of SSU $[16,17,19,39]$ and D2-D3 [20, 39] rDNA data using various methods and species sampling generally agree on the monophyly of most tylenchid clades and contradict classic morphology based classifications. In the SSU-ITS1-5.8S-LSU tree (Figure 5), the monophyletic Tylenchida consists of three major robust clades. The first clade diverges into six groups: (1) the "Tylenchidae (part 2)" (by [17]), (2) the Tylodoridae (represented by the two genera, Cephalenchus and Eutylenchus [83]), (3) Boleodorinae + "Tylenchidae (part 1)" (by [Bert]), (4) the Merliniidae [130], (5) Criconematina + Sphaeronematidae + selected Tylenchina, and (6) Belonolaimidae + "Hoplolaimina." The Merliniidae group corresponds to Clade C in [19] and includes partially the polyphyletic "Telotylenchinae" [131], "Pratylenchidae", and "Hoplolaimina" (Psilenchus cf. hilarulus). Group (5) corresponds to Clade 12A in [129], where Sphaeronematidae (Sphaeronema and Meloidoderita) were earlier shown to be closely related to Criconematina [20,89], and selected Ecphyadophoridae + Ottolenchus + Malenchus were found to represent a monophyletic clade within the paraphyletic Tylenchina likely to be related to the Criconematina $[18,82]$. Group (6) corresponds to Clade VII in [20], Clade 12B in [129], and Clade A + Clade B in [19]. Belonolaimidae (the genera Belonolaimus and Ibipora) tend to occupy the basal position. Clade A in [19] contains a "long branch" of the burrowing nematode Radopholus similes ("Pratylenchidae") in sister position to the Hoplolaimidae $[17,19]$. This nematode occupies a similar position relative to the Hoplolaimidae in the SSU-ITS1-5.8S-LSU tree, and we consider this unlikely to be an LBA artefact. Similarly to [95], Carphodorus and Morulaimus that belong to the classic Belonolaimidae comprise the basal branch of Clade A sensu [19]. The clade corresponding to Clade B in [19] contains Meloidogynidae, Dolichodoridae, paraphyletic Pratylenchidae, and a part of Telotylenchidae.

The second major clade of the Tylenchida includes representatives of the classic infraorder Anguinata, with a wellsupported monophyletic origin, except for a few species. They belong outside the second clade and may initially have been wrongly identified.

The third major clade includes representatives of the classic suborder Hexatylina and consists of two groups. The smaller one unites the three species of Sphaerularia, Helionema sp., cf. Hexatylus sp., Deladenus sp. PDL-2005, and Nothotylenchus acris (Anguinata: Nothotylenchidae). It is further referred to as the Sphaerularioidea according to the type genus. The larger group contains the clade of studied flea parasites and members of the superfamilies Iotonchioidea (Skarbilovinema spp., Parasitylenchus spp., and Wachekitylenchus bovieni) and Sphaerularioidea (Allantonema mirable, Bradynema spp., Howardula spp., and Contortylenchus sp. (fam. Allantonematidae); Deladenus durus, Deladenus proximus, Deladenus siricidicola, Fergusobia spp., and Gymnotylenchus sp. (fam. Neotylenchidae)). One species of the Anguinata, Sychnotylenchus sp., also joins the larger group. Our study renders the genera Howardula and Deladenus paraphyletic, as was earlier shown in $[19,39,71,119]$.

The genus Howardula is paraphyletic in published rDNA and mitochondrial COI phylogenies [71]. Such characters of Howardula as the degeneration of oesophagus, tail shape, and the absence of stylet in males seem to have evolved independently by convergence. The paraphyletic genus Deladenus is more closely related to either ancestral forms of the Hexatylina or forms typical to the Anguinata. The infraorder Anguinata includes soil-dwelling nematodes, mostly mycetophagous or parasitizing various parts of plants. However, an unidentified entomoparasitic nematode was also grouped within the Anguinoidea [39]. The life cycle of Deladenus spp. is an irregular alternation of free-living and entomoparasitic forms. The nematode $D$. siricidicola is able of producing an unlimited number of free-living generations in the absence of the host larvae of siricid 


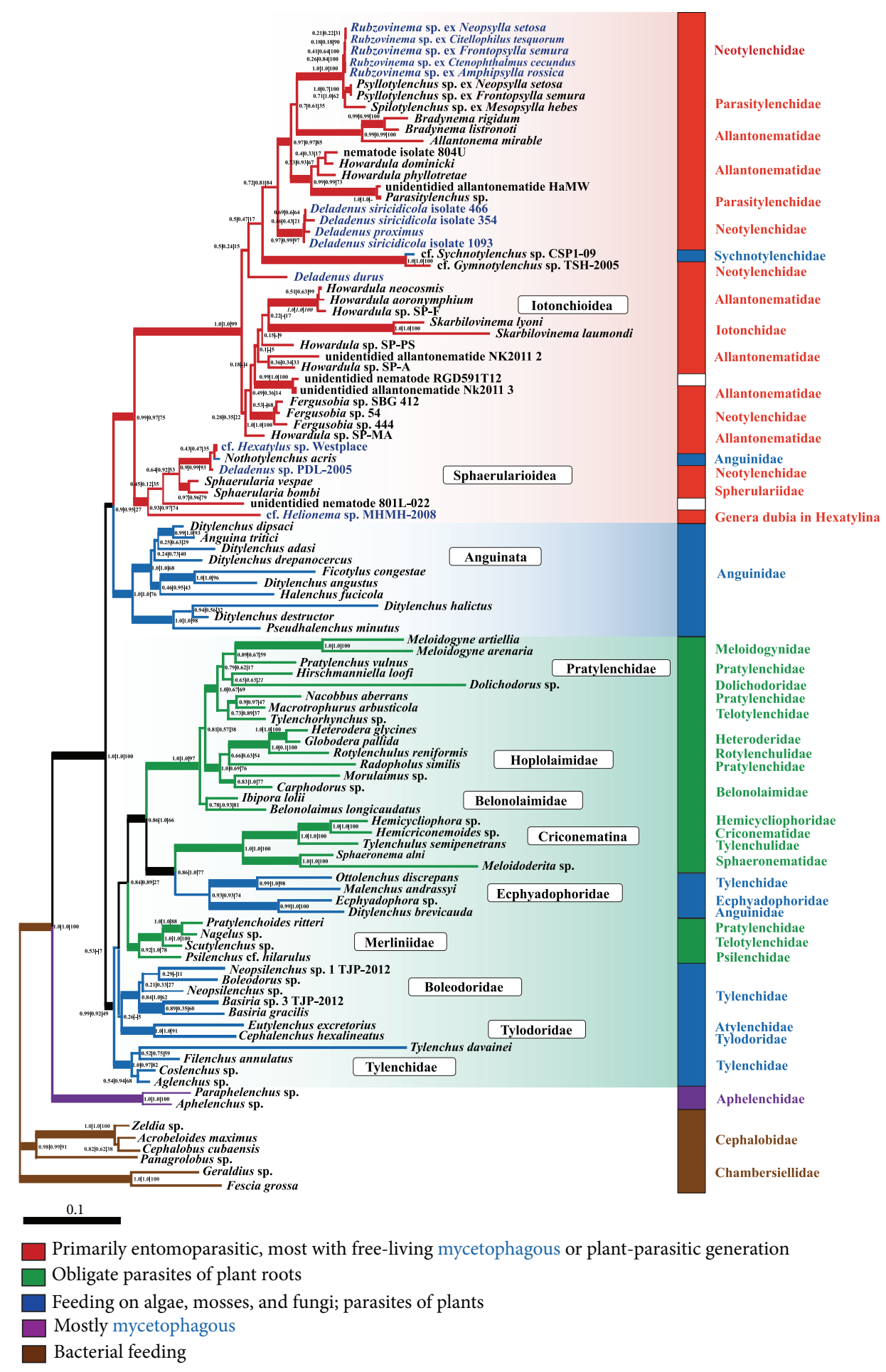

FIgure 5: Phylogenetic tree of Tylenchida, inferred from SSU-ITS1-5.8S-LSU rDNA sequences. Topology was inferred using the PhyloBayes software (maxdiff $=0.36$ ). Node support values are shown as follows: the first two values are Bayesian posterior probability assessed using the PhyloBayes and MrBayes software, respectively, and the third is bootstrap support assessed by the ML method. Thick lines lead to the nodes, in which at least one support value of posterior probability is 0.95 and higher. Names of clades (framed) are mainly given by type genera included in them (with the exception of Iotonchioidea). Formal taxonomic position (family by [8]) is shown on the right to the color bar. Colors indicate the ecologies (see the legend). Names of the species of Hexatylina that have a mycetophagous stage in their life cycle are shown in blue. The three robust major branches of Tylenchida are marked by gradient. 


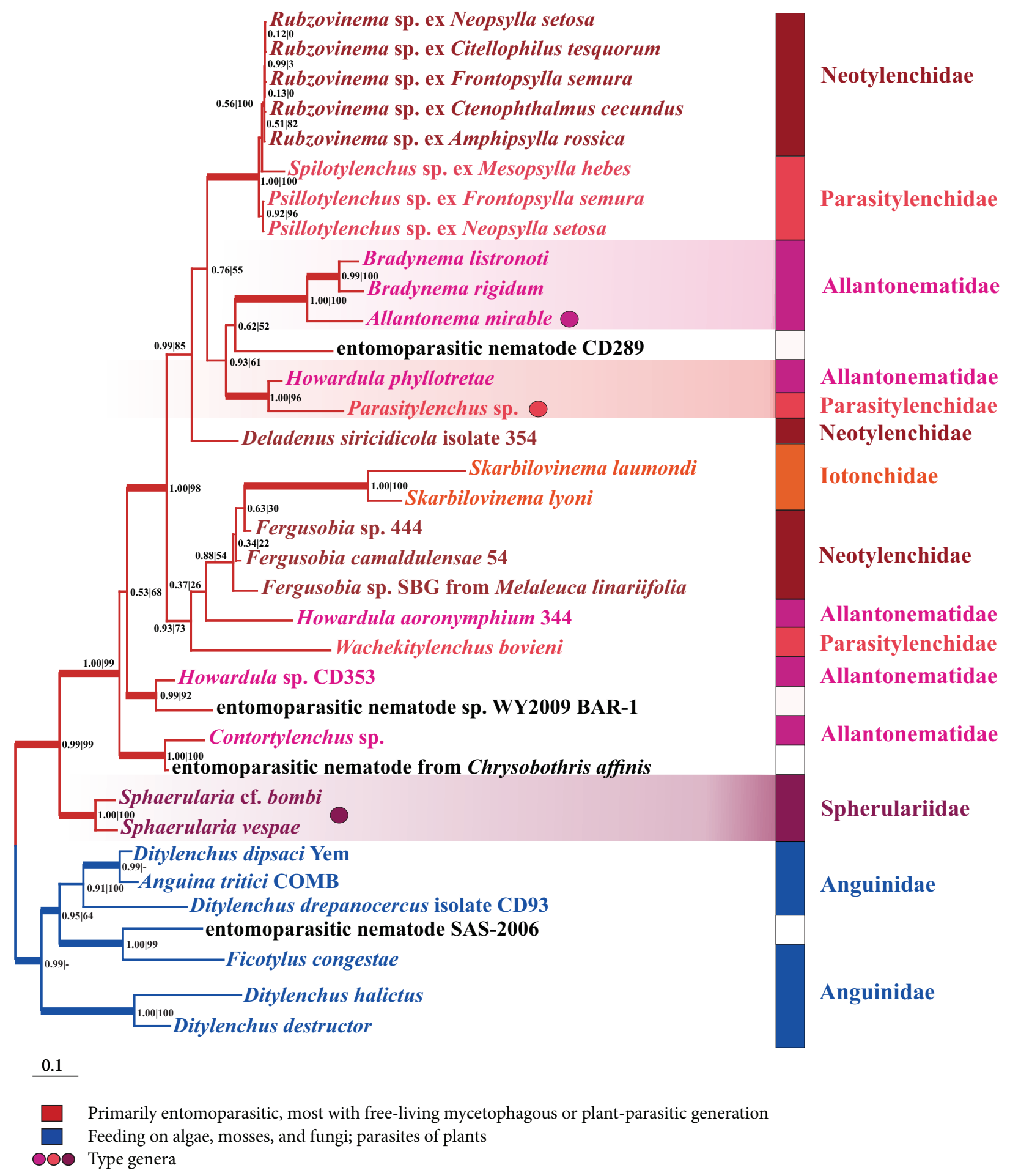

FIGURE 6: Phylogenetic tree of Hexatylina, inferred from D3 expansion segment of LSU rDNA. Topology was inferred using the PhyloBayes software. Node support values are shown as follows: Bayesian posterior probability/bootstrap support assessed by the ML method. Thick lines indicate the nodes supported at the level of 0.95 and higher. Color of lines indicates the ecologies (see the legend). Names of species were shown in different colors indicating their taxonomic position. Three families that include their type genera (shown as circles) are marked by gradient. 
TABLE 7: Results of tree topology tests for alternative hypotheses on (1) the initial divergence of Tylenchida (Figure 4) and on (2) the relationships within the monophyletic branch that includes the studied group of nematodes parasitizing fleas (designated by asterisk).

\begin{tabular}{|c|c|c|c|c|c|c|c|c|c|}
\hline Topology & Rank & obs & $\mathrm{au}$ & $\mathrm{np}$ & $\mathrm{bp}$ & $\mathrm{pp}$ & $\mathrm{kh}$ & sh & c-ELW \\
\hline \multicolumn{10}{|c|}{1} \\
\hline$(((\mathrm{H}, \mathrm{An}), \mathrm{T}), \mathrm{o})$ & 1 & -1.8 & 0.787 & 0.415 & 0.402 & 0.804 & 0.663 & 0.969 & 0.4197 \\
\hline$((\mathrm{An},(\mathrm{H}, \mathrm{T})), \mathrm{o})$ & 2 & 4.1 & 0.326 & 0.198 & 0.205 & 0.013 & 0.254 & 0.623 & 0.1848 \\
\hline$((\mathrm{H},(\mathrm{An}, \mathrm{T})), \mathrm{o})$ & 3 & 6.9 & 0.061 & 0.013 & 0.014 & 0.001 & 0.101 & 0.492 & 0.0186 \\
\hline \multicolumn{10}{|c|}{2} \\
\hline$((((*, \mathrm{Al}), \mathrm{P}), \mathrm{Ds}), \mathrm{o})$ & 1 & -1.8 & 0.787 & 0.415 & 0.402 & 0.804 & 0.663 & 0.969 & 0.4197 \\
\hline$((((*, \mathrm{P}), \mathrm{Al}), \mathrm{Ds}), \mathrm{o})$ & 2 & 1.8 & 0.495 & 0.242 & 0.247 & 0.130 & 0.337 & 0.813 & 0.2249 \\
\hline$(((*,(\mathrm{Al}, \mathrm{P})), \mathrm{Ds}), \mathrm{o})$ & 3 & 2.7 & 0.371 & 0.110 & 0.105 & 0.052 & 0.243 & 0.824 & 0.1209 \\
\hline$((*,((\mathrm{Al}, \mathrm{P}), \mathrm{Ds})), \mathrm{o})$ & 6 & 15.7 & 0.063 & 0.024 & 0.025 & $1 e-007$ & 0.053 & 0.153 & 0.0272 \\
\hline$(((*, \mathrm{Ds}),(\mathrm{Al}, \mathrm{P})), \mathrm{o})$ & 7 & 18.3 & 0.013 & 0.002 & 0.002 & $9 e-009$ & 0.020 & 0.096 & 0.0028 \\
\hline
\end{tabular}

Al: Allantonematidae, An: Anguinata, Ds: Deladenus siricidicola -D. proximus group, H: Hexatylina, P: Parasitylenchidae, T: Tylenchina, o: outgroup.

pine-killing wood wasps [132]. Like in Anguinata, the freeliving forms of Deladenus spp. are fungal feeding. Such characters of Deladenus asthe mycetophagy, enlargement of subventral glands in entomoparasitic females versus their reduction in free-living forms, the hypertrophy of dorsal glands, and stylet reduction in free-living forms seem to be symplesiomorphic. Resemblance with the Anguinata is also typical of other mycetophagous free-living forms: Hexatylus (Neotylenchidae), Rubzovinema (Neotylenchidae), Prothallonema (Sphaerularioidae) Helionema (Hexatylina dubia), and Paurodontidae. For the latter, the entomoparasitic stage is expected but has never been observed. The relationship between the Hexatylina and Anguinata was earlier hypothesized based on morphology $[7,8,130,133,134]$. On rDNA phylogenies of tylenchids, the monophyly of the Hexatylina + Anguinata is either supported [19] or not rejected [20]. In the SSU-ITS1-5.8S-LSUrDNA tree obtained in this study, the monophyly of the Hexatylina + Anguinata has the Bayesian posterior probability of 0.91 , but the maximum-likelihood bootstrap support is low; the AU and Kishino and Hasegawa tests did not discriminate between alternative hypotheses.

According to our SSU-ITS1-5.8S-LSU rDNA phylogeny (Figure 5), the major robust branches of the Tylenchida are incongruent with morphology-based classifications suggesting three rather than four suborders (the rank is adopted from morphological systems of tylenchids). Among them, the Hexatylina and Anguinata (both are monophyletic) are likely to be sister groups. The third emerged suborder includes representatives of three classic suborders: Tylenchina, Hoplolaimina, and Criconematina, among which only the latter does not contradict morphology-based classifications.

Considering ecological traits coded in Figure 5, the mycetophagy and/or facultative ectophytoparasitism are likely to be ancestral in the Tylenchida. Sedentary phytoparasites (root-knot species of Meloidogyne, the false root-knot genus Nacobbus, and cyst-forming Heterodera and Globodera) and other obligate endoparasites of plants evolved several times from free-living or facultative sedentary forms, as it was previously hypothesized in accordance with the concept of evolutionary trend to endoparasitism in phytonematodes [135]. Similarly, obligate endoparasites of insects from the
Hexatylina are likely to have evolved from mycetophagous forms, with some species retaining the ancestral mycetophageous stage in the life cycle (e.g., species of the paraphyletic genus Deladenus and flea nematodes of the genus Rubzovinema). An interesting specific case in the Hexatylina is the genus Fergusobia that includes plant parasites associated with insects $[68,70]$, which may have transited to plant parasitism via entomoparasitism [39].

4.2. Ribosomal DNA Phylogeny of the Flea Nematodes and Their Classification. The nematodes of fleas do not group with the families known as their relatives in morphologybased systems, as these families do not form monophyletic groups in the tree. However, they do group with both type genera of the families Parasitylenchidae and Allantonematidae (Parasitylenchus and Allantonema, resp.). This grouping is preceded by a successive divergence of Deladenus durus and Deladenus siricidicola (Figure 5). As mentioned above, the pronounced free-living form in Deladenus seems to be ancestral to this group.

Only 31 tylenchid species that parasitize in fleas have been described to date. They differ by morphology, life cycle, and the host specificity, and belong to the five genera: Spilotylenchus (8 species), Psyllotylenchus (20 species), Incurvinema (1 species) Kurochkinitylenchus (1 species), and Rubzovinema (1 species). According to the classification of Siddiqi [8], the genera Spilotylenchus and Psyllotylenchus belong to the family Parasitylenchidae, whereas the genus Rubzovinema is a member of the Neotylenchidae. The two families represent two superfamilies, Iotonchioidea and Sphaerularioidea, respectively. All rDNA phylogenies published to date suggest that these superfamilies are paraphyletic $[19,20,39]$, which is also inferred in our study with an extensive gene and taxon sampling.

A high degree of rDNA similarity in the three studied species suggests a closer relationship of these species than that assumed by the accepted system of classification. Earlier, Slobodyanyuk proposed to unite all known flea parasites into one family, the Spilotylenchidae. Its four subfamilies, Spilotylenchinae, Rubzovinematinae, Psyllotylenchinae, and Kurochkinitylenchinae, are discriminated based on the life 
cycle features [28]. In Spilotylenchinae and Rubzovinematinae, the entomoparasitic stage is represented by parasitic females of one heterosexual generation. In Psyllotylenchinae, in addition to the heterosexual generation, a parthenogenetic generation occurs in the flea haemocoel. In Kurochkinitylenchinae, two heterosexual generations exist in the haemocoel: the first generation produces parasitic females and the second generation produces both females and males [28]. Siddiqi also considered the unification of all flea tylenchids into one family but observed the need for further evidence in support [8].

Our results strongly suggest the inclusion of the three genera, Rubzovinema, Psyllotylenchus, and Spilotylenchus, in one family, the Spilotylenchidae [28]. The ribosomal DNA genetic distance within the family Spilotylenchidae is much smaller than that of certain tylenchid genera, for example, Meloidogyne (Figure 4) or Pratylenchus [19, 84].

4.3. Host Specificity of Flea Nematodes. The majority of tylenchid nematodes are monoxenous or oligoxenous; in particular, flea parasites were thought to be strictly host specific. Earlier papers suggested the lack of strict host specificity in Psyllotylenchus pawlowskyi and Psyllotylenchus viviparous $[13,25]$. However, later these species were found to be heterogeneous and sustained revision [9, 27-29]. Spilotylenchus pawlowskyi and Spilotylenchus caspius were referred to as single-host parasites of the flea Coptopsylla lamellifer $[27,136]$. Kurochkinitylenchus laevicepsi and Spilotylenchus ivashkini also share the same flea host, Nosopsyllus laeviceps $[28,29]$. Before our study, the genus Rubzovinema was known to contain a single species, Rubzovinema ceratophylla, which parasitizes exclusively the flea Citellophilus tesquorum.

We found that at least two out of the three studied species are not single-host parasites. Psyllotylenchus sp. was shown to parasitize two flea species feeding on sousliks, Frontopsylla semura and Neopsylla setosa. Rubzovinema sp. was found on five flea species feeding on different rodent hosts: C. tesquorum, F. semura, N. setosa (all sampled from sousliks), Ctenophtalamus secundus, and Amphipsylla rossica (all sampled from voles). A. rossica, F. semura, and C. tesquorum belong to different families of the superfamily Ceratophylloidea (Leptopsyllidae and Ceratophyllidae), whereas $C$. secundus and $N$. setosa belong to the superfamily Hystrichopsylloidea. Unlike the host-specific $R$. ceratophylla, the studied Rubzovinema sp. parasitizes taxonomically distant fleas feeding on different rodents. Thus, the common opinion that flea nematodes are strictly host specific should be revisited.

As the two species of Rubzovinema demonstrate, even closely related parasites may exhibit different host range size. Among other known examples are the entomoparasitic nematodes of the genus Howardula parasitizing various beetles and flies [71, 137, 138], many phytonematodes [8], sibling species of parasitoid flies [128], and herbivorous insects [139]. The host range of parasites is an indicator of their evolutionary strategy in the ecosystem. Multihost parasites can be considered ecological generalists, in contrast to specialists that coevolve with a particular host. Generalists and specialists play different roles in the ecosystem [140], where they keep in balance, taking advantages and disadvantages of the two strategies. The advantages of generalization are yet to be explained by evolutionary biologists, whereas advantages of specialization are obvious, and it is generally accepted that evolution favors specialism [141, 142]. In the flea parasites, this trend is demonstrated by a greater species diversity of ecological specialists, the genera Spilotylenchus and Psyllotylenchus.

Nevertheless, the generalist Rubzovinema sp. was most abundant in the studied samples, which indicates that extending the host range may be evolutionarily successful. Besides the need to combat the immune response of several hosts, which is a requirement to widen the hosts range [143], the free-living stage of Rubzovinema sp. is to adapt to diverse microbioclimatic conditions of complex environments of rodent habitats. Multihost parasites pay a cost of adapting to alternative conditions $[141,144]$ compensated by stable survival of the species. Considering the spatial and temporal dynamics of flea populations feeding on a particular rodent host (one or two flea species usually dominate over a sampling season), multihost nematode parasites gain an advantage of their relative independence of population waves of either flea hosts or their rodent hosts. A higher infestation rate observed for Rubzovinema sp., compared to the two other studied species, may be an indicator of a greater ecological plasticity of this multihost parasite.

4.4. Entomoparasitic Nematodes in Natural Foci of Plague. In natural foci of plague, the epizootic dynamics are influenced by numerous climatic and biotic factors. The spatial and temporal population dynamics of the plague agent, Y. pestis, affect the population dynamics of the flea vectors and their mammalian hosts. Members of the transmission route of the plague agent also closely interact with other living organisms. For example, parasites of fleas that in turn feed on rodents are hyperparasites that play the role of high-level control agents on the ecosystem level, the role that entomoparasitic nematodes share with the bacterial plague agent. Highlevel control agents render the epidemiological state of a natural focus of disease less predictable. On the one hand, a lower density of the flea vector population reduces the plaque transmission rate; on the other, its growth causes an exponential decay of the host rodent population [145] below its epidemiological threshold, above which there is a threat of spillover of plague infection into human population [145]. Hypothetically, nematode-induced decrease of flea population is able to increase the number of rodents above the threshold and thus trigger an epidemic. The dual effect of high-level control agents is well exemplified by cases, when during plague episodes the extermination of rodents by humans causes the return of infection through stimulating the migration of fleas, the plaque vectors [5].

The studied entomoparasitic nematodes possess high potential as control agents of the flea vectors of plague owing to their high propagation rate within the flea host (Figure 2) and high infestation level (up to $21 \%$ observed in this study and from 50 to $60 \%$, as estimated by other authors 
$[10,11])$. One of the studied nematode species, Rubzovinema sp., is a multihost parasite. Host-specific parasites reach the optimal level of pathogenicity by maintaining the tradeoff between pathogenicity and transmissibility. Adding of a new host to a multihost system makes the model more complicated [141]. The multihost parasite Rubzovinema sp. is expected to exhibit different levels of pathogenicity with respect to different flea hosts which, in turn, play different roles in the transmission of plague. Epizootics cause sporadic mortality in local populations of all members involved in the interaction with the plague agent, and their survival is contingent on migrations within a metapopulation. It is the case when the Cope's law $[139,146]$ governs the extinction of specialists on a shorter time scale rather than a geological period, and evolution may favor the ecological generalists, such as Rubzovinema sp.

Some authors surmised the involvement of entomoparasitic nematodes in the transmission of the plague agent [4], as it was observed that biofilms of Yersinia pestis adhere to cuticle receptors of Caenorhabditis elegans [147-149]. In this perspective, nematodes parasitizing fleas in natural foci of plague take on greater importance, as they may provide for the transmission route that does not include a mammal [4]. Further studies will clarify the role of flea nematodes in the transmission of plague infection.

\section{Conflict of Interests}

The authors declare that there is no conflict of interests regarding the publication of this paper.

\section{Acknowledgments}

The authors thank G. S. Mirzaeva for help with PCR amplification and rDNA fragment analysis, N. V. Popov and the staff of the Laboratory of Epizootics Monitoring for advice and assistance in collecting and processing rodent samples, and, particularly, A. N. Porshakov for help in identification of flea specimens. They also thank O. V. Slobodyanyuk for helpful discussions of results, S. E. Spiridonov for advice on cultivation of entomoparasitic nematodes, S. A. Subbotin for valuable comments on the earlier version of the paper, and E. Yu. Talanova and L. Yu. Rusin for discussions of its final version, and E. A. Musatkina for assistance with the manuscript preparation. They are grateful to the Supercomputer Center of Moscow State University (http://parallel.ru/cluster) and the Bioportal of the University of Oslo (http://www.bioportal.uio.no) for providing computing resources.

\section{References}

[1] A. W. Bacot and C. J. Martin, "Observations on the mechanism of the transmission of plague by fleas," The Journal of Hygiene, vol. 13, supplement 3, pp. 423-439, 1914.

[2] V. V. Kutyrev, G. A. Eroshenko, N. V. Popov, N. A. Vidyaeva, and N. P. Konnov, "Molecular mechanisms of interaction of the plague agent with invertebrates," Molecular Genetics, Microbiology and Virology, vol. 24, no. 4, pp. 7-12, 2009.
[3] E. N. Pavlovsky, Natural Focality of Transmissive Diseases in Connection with Landscape Epidemiology of Zooanthroponoses, Moscow, Russia, 1964.

[4] N. V. Popov, E. I. Koshel, G. A. Eroshenko, and V. V. Kutyrev, "Formation of modern concepts on the mechanism of plague enzooty," Problems of Particularly Dangerous Infections, vol. 3, no. 109, pp. 5-8, 2011.

[5] M. J. Keeling and C. A. Gilligan, "Bubonic plague: a metapopulation model of a zoonosis," Proceedings of the Royal Society B, vol. 267, no. 1458, pp. 2219-2230, 2000.

[6] R. A. Bedding, R. J. Akhurst, and H. K. Kaya, Nematodes and the Biological Control of Insect Pests, CSIRO Press, Melbourne, Australia, 1993.

[7] M. R. Siddiqi, Tylenchida Parasites of Plants and Insects, vol. 645 of Commonwealth Agricultural Bureaux, Farnham Royal, Slough, UK, 1986.

[8] M. R. Siddiqi, Tylenchida: Parasites of Plants and Insects, CABI, Wallingford, UK, 2nd edition, 2000.

[9] I. A. Rubtsov, Parasites and Enemies of Fleas, Nauka, Leningrad, Russia, 1981.

[10] Y. A. Morozov, "About infestation with fleas great gerbils different ages," in Proceedings of the Conference Anti-Plague Facilities in Central Asia and Kazakhstan, pp. 337-338, AlmaAta, 1974.

[11] Y. A. Morozov, "Effect of infestation of nematode on reproduction of fleas gerbils in Muyunkum," in Proceedings of the Conference Anti-Plague Facilities in Central Asia and Kazakhstan, pp. 338-340, Alma-Ata, 1974.

[12] J. Deunff, Parasites de Siphonaptères. Étude de la systématique, de la biologie et du pouvoir pathogène des Tylenchides (Nematodea) dans une perspective de lutte biologique [Ph.D. thesis], Etat Sc. Pham, Rennes, France, 1984.

[13] Y. V. Kurochhkin, “The nematode Heterotylenchus pawlowskyi sp. n., castrating flea-vectors of plague," Doklady Akademyi Nauk SSSR, vol. 135, pp. 1281-1284, 1960.

[14] M. L. Blaxter, P. De Ley, J. R. Garey et al., "A molecular evolutionary framework for the phylum Nematoda," Nature, vol. 392, no. 6671, pp. 71-75, 1998.

[15] P. De Ley and M. L. Blaxter, "Systematic Position and Phylogeny," in The Biology of Nematodes, D. L. Lee, Ed., Taylor \& Francis, London, UK, 2002.

[16] B. H. M. Meldal, N. J. Debenham, P. De Ley et al., "An improved molecular phylogeny of the Nematoda with special emphasis on marine taxa," Molecular Phylogenetics and Evolution, vol. 42, no. 3, pp. 622-636, 2007.

[17] W. Bert, F. Leliaert, A. R. Vierstraete, J. R. Vanfleteren, and G. Borgonie, "Molecular phylogeny of the Tylenchina and evolution of the female gonoduct (Nematoda: Rhabditida)," Molecular Phylogenetics and Evolution, vol. 48, no. 2, pp. 728744, 2008.

[18] M. Holterman, A. Van Der Wurff, S. Van Den Elsen et al., "Phylum-wide analysis of SSU rDNA reveals deep phylogenetic relationships among nematodes and accelerated evolution toward crown clades," Molecular Biology and Evolution, vol. 23, no. 9, pp. 1792-1800, 2006.

[19] M. Holterman, G. Karssen, S. Van Den Elsen, H. Van Megen, J. Bakker, and J. Helder, "Small subunit rDNA-based phylogeny of the tylenchida sheds light on relationships among some highimpact plant-parasitic nematodes and the evolution of plant feeding," Phytopathology, vol. 99, no. 3, pp. 227-235, 2009. 
[20] S. A. Subbotin, D. Sturhan, V. N. Chizhov, N. Vovlas, and J. G. Baldwin, "Phylogenetic analysis of Tylenchida Thorne, 1949 as inferred from D2 and D3 expansion fragments of the 28S rRNA gene sequences," Nematology, vol. 8, no. 3, pp. 455-474, 2006.

[21] S. A. Subbotin, D. Sturhan, B. J. Adams et al., "Molecular phylogeny of the order Tylenchida: analysis of nuclear ribosomal RNA genes," Journal of Nematology, vol. 38, no. 2, pp. 296-296, 2006.

[22] H. Launay, J. Deunff, and O. Bain, "Spilotylenchus arthuri, gen. n., sp. n. (Nematodea, Tylenchida: Allantonematidae), parasite of Spilopsyllus cuniculi (Dale, 1878) (Siphonaptera: Pulicidae)," Annales de Parasitologie Humaine et Comparee, vol. 58, no. 2, pp. 141-150, 1983.

[23] H. Launay and J. Deunff, "Spilotylenchus maisonabei n. sp. (Nematoda: Allantonematidae) parasite of the European rabbit flea Spilopsyllus cuniculi (Dale, 1878) (Siphonaptera: Pulicidae)," Annales de Parasitologie Humaine et Comparee, vol. 13, pp. 293296, 1990.

[24] C. Laumond and J. C. Beaucournu, "Neoparasitylenchus megabothridis n. sp. (Tylenchida: Allantonematidae) parasite of Megabothris tubidus (Siphonaptera: Ceratophyllidae); observations on fleas tylenchides in the S.W. of Europa (author's transl)," Annales de Parasitologie Humaine et Comparee, vol. 53, no. 3, pp. 291-302, 1978.

[25] G. O. Poinar Jr. and B. C. Nelson, "Psyllotylenchus viviparus, n. gen., n. sp. (Nematodea: Tylenchida: Allantonematidae) parasitizing fleas (Siphonaptera) in California," Journal of Medical Entomology, vol. 10, no. 4, pp. 349-354, 1973.

[26] V. O. Slobodyanyuk, "Validation of genus Rubzovinema gen.n. (Sphaerularioidea) and redescription of species Rubzovinema ceratophylla comb.n. parasite of fleas Citellophillus tesquorum," Zoological Journal, vol. 70, no. 9, pp. 33-43, 1991.

[27] O. V. Slobodyanyuk, "Revision of the species Psyllotylenchus pawlowskyi (Kurochkin, 1960) Poinar \& Nelson, 1973. I. Redescription of Spilotylenchus pawlowskyi (sensu stricto) comb. n. (Tylenchida: Allantonematidae)," Russian Journal of Nematology, vol. 5, no. 2, pp. 103-112, 1997.

[28] O. V. Slobodyanyuk, "Revision of the species Psyllotylenchus pawlowskyi (Kurochkin, 1960) Poinar \& Nelson, 1973. II. Description of Kurochkinitylenchus laevicepsi gen. n., sp. n. and Spilotylenchidae fam. n," Russian Journal of Nematology, vol. 7, no. 1, pp. 1-18, 1999.

[29] O. V. Slobodyanyuk, "Revision of the species Psyllotylenchus pawlowskyi (Kurochkin, 1960) Poinar \& Nelson, 1973. III. Description of Spilotylenchus ivashkini sp. n," Russian Journal of Nematology, vol. 8, no. 1, pp. 45-55, 2000.

[30] J. Deunff and H. Launay, "Psyllotylenchus chabaudi, n. sp. (Nematodea, Tylenchida: Allantonematidae), a parasite of Nosopsyllus fasciatus (Bosc) (Siphonaptera: Ceratophyllidae)," Annales de Parasitologie Humaine et Comparee, vol. 59, no. 3, pp. 263-270, 1984.

[31] J. Deunff, H. Launay, and J. C. Beaucournu, "Incurvinema helicoides n. gen., n. sp. Nematodea, Tylenchida: allantonematidae parasite de Rhadinopsylla pentacantha (Rothschild, 1897) (Siphonaptera : Hystrichopsyllidae)," Annales de Parasitologie Humaine Et Comparée, vol. 60, pp. 739-746, 1985.

[32] A. T. De Grisse, "Redescriptions ou modifications de quelques techniques utilisées dans l'étude des nématodes phytoparasites," Mededelingen Rijksfakulteit Landbouwwetenschappen Gent, vol. 34, pp. 351-369, 1969.
[33] X. Huang, "A contig assembly program based on sensitive detection of fragment overlaps," Genomics, vol. 14, no. 1, pp. 1825, 1992.

[34] T. A. Hall, "BioEdit: a user-friendly biological sequence alignment editor and analysis program for Windows 95/98/NT," Nucleic Acids Symposium Series, vol. 41, pp. 95-98, 1999.

[35] L. Medlin, H. J. Elwood, S. Stickel, and M. L. Sogin, "The characterization of enzymatically amplified eukaryotic 16S-like rRNA-coding regions," Gene, vol. 71, no. 2, pp. 491-499, 1988.

[36] V. N. Chizhov, O. A. Chumakova, S. A. Subbotin, and J. G. Baldwin, "Morphological and molecular characterization of foliar nematodes of the genus Aphelenchoides: A. fragariae and A. ritzemabosi (Nematoda: Aphelenchoididae) from the Main Botanical Garden of the Russian Academy of Sciences, Moscow," Russian Journal of Nematology, vol. 14, no. 2, pp. 179-184, 2006.

[37] G. Van der Auwera, S. Chapelle, and R. De Wächter, "Structure of the large ribosomal subunit RNA of Phytophthora megasperma, and phylogeny of the oomycetes," FEBS Letters, vol. 338, no. 2, pp. 133-136, 1994.

[38] S. A. Subbotin, N. Vovlas, R. Crozzoli et al., "Phylogeny of Criconematina Siddiqi, 1980 (Nematoda: Tylenchida) based on morphology and D2-D3 expansion segments of the 28S rDNA gene sequences with application of a secondary structure model," Nematology, vol. 7, pp. 927-944, 2005.

[39] V. N. Chizhov, N. N. Butorina, and S. A. Subbotin, "Entomoparasitic nematodes of the genus Skarbilovinema: S. laumondi and S. lyoni (Nematoda: Tylenchida), parasites of the flies of the family Syrphidae (Diptera), with phylogeny of the suborder Hexatylina," Russian Journal of Nematology, vol. 20, no. 2, pp. 141-155, 2012.

[40] S. F. Altschul, T. L. Madden, A. A. Schäffer et al., "Gapped BLAST and PSI-BLAST: a new generation of protein database search programs," Nucleic Acids Research, vol. 25, no. 17, pp. 3389-3402, 1997.

[41] R. C. Edgar, "MUSCLE: multiple sequence alignment with high accuracy and high throughput," Nucleic Acids Research, vol. 32, no. 5, pp. 1792-1797, 2004.

[42] M. Nei and S. Kumar, Molecular Evolution and Phylogenetics, Oxford University Press, Oxford, UK, 2000.

[43] N. Lartillot, T. Lepage, and S. Blanquart, "PhyloBayes 3: a Bayesian software package for phylogenetic reconstruction and molecular dating," Bioinformatics, vol. 25, no. 17, pp. 2286-2288, 2009.

[44] N. Lartillot and H. Philippe, "A Bayesian mixture model for across-site heterogeneities in the amino-acid replacement process," Molecular Biology and Evolution, vol. 21, no. 6, pp. 10951109, 2004.

[45] J. P. Huelsenbeck and F. Ronquist, "MRBAYES: bayesian inference of phylogenetic trees," Bioinformatics, vol. 17, no. 8, pp. 754-755, 2001.

[46] C. Lanave, G. Preparata, C. Saccone, and G. Serio, "A new method for calculating evolutionary substitution rates," Journal of Molecular Evolution, vol. 20, no. 1, pp. 86-93, 1984.

[47] A. Stamatakis, "Maximum likelihood-based phylogenetic analyses with thousands of taxa and mixed models," Bioinformatics, vol. 22, pp. 2688-2690, 2006.

[48] H. Shimodaira, "An approximately unbiased test of phylogenetic tree selection," Systematic Biology, vol. 51, no. 3, pp. 492$508,2002$. 
[49] H. Kishino and M. Hasegawa, "Evaluation of the maximum likelihood estimate of the evolutionary tree topologies from DNA sequence data, and the branching order in Hominoide," Journal of Molecular Evolution, vol. 29, no. 2, pp. 170-179, 1989.

[50] H. Shimodaira and M. Hasegawa, "CONSEL: for assessing the confidence of phylogenetic tree selection," Bioinformatics, vol. 17, no. 12, pp. 1246-1247, 2002.

[51] K. Strimmer and A. Rambaut, "Inferring confidence sets of possibly misspecified gene trees," Proceedings of the Royal Society B, vol. 269, no. 1487, pp. 137-142, 2002.

[52] H. A. Schmidt, K. Strimmer, M. Vingron, and A. Von Haeseler, "TREE-PUZZLE: maximum likelihood phylogenetic analysis using quartets and parallel computing," Bioinformatics, vol. 18, no. 3, pp. 502-504, 2002.

[53] R. D. M. Page, “TreeView: an application to display phylogenetic trees on personal computers," Computer Applications in the Biosciences, vol. 12, no. 4, pp. 357-358, 1996.

[54] O. Holovachov, S. Bostrom, I. T. De Ley et al., "Morphology, molecular characterisation and systematic position of the genus Cynura Cobb, 1920 (Nematoda: Plectida)," Nematology, vol. 15, pp. 611-627, 2013.

[55] S. A. Nadler, P. De Ley, M. Mundo-Ocampo et al., "Phylogeny of Cephalobina (Nematoda): molecular evidence for recurrent evolution of probolae and incongruence with traditional classifications," Molecular Phylogenetics and Evolution, vol. 40, no. 3, pp. 696-711, 2006.

[56] O. Holovachov, S. Bostrom, S. A. Nadler, and P. De Ley, "Systematics and phylogenetic position of the genus Tricirronema Siddiqi, 1993 (Cephalobomorpha)," Journal of Nematode Morphology and Systematics, vol. 12, no. 2, 2009.

[57] K. Kiontke, A. Barrière, I. Kolotuev et al., "Trends, stasis, and drift in the evolution of nematode vulva development," Current Biology, vol. 17, no. 22, pp. 1925-1937, 2007.

[58] R. Campos-Herrera, F. E. El-Borai, and L. W. Duncan, "Wide interguild relationships among entomopathogenic and freeliving nematodes in soil as measured by real time qPCR," Journal of Invertebrate Pathology, vol. 111, no. 2, pp. 126-135, 2012.

[59] M.-A. Félix, P. De Ley, R. J. Sommer et al., "Evolution of vulva development in the Cephalobina (Nematoda)," Developmental Biology, vol. 221, no. 1, pp. 68-86, 2000.

[60] S. Boström, O. Holovachov, and S. A. Nadler, "Description of Scottnema lindsayae Timm, 1971 (Rhabditida: Cephalobidae) from Taylor Valley, Antarctica and its phylogenetic relationship," Polar Biology, vol. 34, no. 1, pp. 1-12, 2011.

[61] J. W. Waceke, D. J. Bumbarger, M. Mundo-Ocampo, S. A. Subbotin, and J. G. Baldwin, "Zeldia spannata n. sp. (Nematoda: Cephalobidae) from the Mojave Desert, California," Journal of Nematode Morphology and Systematics, vol. 8, no. 1, pp. 57-67, 2005.

[62] S. Kumari, "Aphelenchus avenae (Nematoda: Aphelenchidae) under the rhizosphere of Brassica napus," Helminthologia, vol. 49, no. 1, pp. 57-59, 2012.

[63] H. Iwahori, K. Tsuda, N. Kanzaki, K. Izui, and K. Futai, "PCRRFLP and sequencing analysis of ribosomal DNA of Bursaphelenchus nematodes related to pine wilt disease," Fundamental and Applied Nematology, vol. 21, no. 6, pp. 655-666, 1998.

[64] L. K. Carta, A. M. Skantar, Z. A. Handoo, and M. A. Baynes, "Supplemental description of Paraphelenchus acontioides (Tylenchida: Aphelenchidae, Paraphelenchinae), with ribosomal DNA trees and a morphometric compendium of female Paraphelenchus," Nematology, vol. 13, no. 8, pp. 887-899, 2011.

[65] Y. Zeng, R. M. Giblin-Davis, Y. Weimin, G. Bélair, G. Boivin, and K. W. Thomas, "Bradynema listronoti n. sp. (Nematoda: Allantonematidae), a parasite of the carrot weevil Listronotus oregonensis (Coleoptera: Curculionidae) in Quebec, Canada," Nematology, vol. 9, no. 5, pp. 609-623, 2007.

[66] K. Rybarczyk-Mydłowska, P. Mooyman, H. van Megen, and Setal, "Small subunit ribosomal DNA-based phylogenetic analysis of foliar nematodes (Aphelenchoides spp.) and their quantitative detection in complex DNA backgrounds," Phytopathology, vol. 102, no. 12, pp. 1153-1160, 2012.

[67] Q. Yu, P. de Groot, I. Leal, C. Davis, W. Ye, and B. Foord, "First report and characterization of Deladenus proximus (Nematoda: Neotylenchidae) associated with Sirex nigricornis (Hymenoptera: Siricidae) in Canada," International Journal of Nematology, vol. 21, no. 2, pp. 139-146, 2012.

[68] W. Ye, R. M. Giblin-Davis, K. A. Davies et al., "Molecular phylogenetics and the evolution of host plant associations in the nematode genus Fergusobia (Tylenchida: Fergusobiinae)," Molecular Phylogenetics and Evolution, vol. 45, no. 1, pp. 123141, 2007.

[69] I. Leal, B. Foord, C. Davis, P. de Groot, X. O. Mlonyeni, and B. Slippers, "Distinguishing isolates of Deladenus siricidicola ,a biological control agent of Sirex noctilio, from North America and the Southern Hemisphere using PCR- RFLP,' Canadian Journal of Forest Research, vol. 42, pp. 1173-1177, 2012.

[70] K. A. Davies, W. Ye, R. M. Giblin-Davis, G. S. Taylor, S. Scheffer, and W. K. Thomas, "The nematode genus Fergusobia (Nematoda: Neotylenchidae): molecular hylogeny, descriptions of clades and associated galls, host plants and Fergusonina fly larvae," Zootaxa, no. 2633, pp. 1-66, 2010.

[71] S. J. Perlman, G. S. Spicer, D. Dewayne Shoemaker, and J. Jaenike, "Associations between mycophagous Drosophila and their Howardula nematode parasites: a worldwide phylogenetic shuffle," Molecular Ecology, vol. 12, no. 1, pp. 237-249, 2003.

[72] C. L. Raak-van den Berg, P. S. van Wielink, P. W. de Jong et al., "Invasive alien species under attack: natural enemies of Harmonia axyridis in the Netherlands," BioControl. In press.

[73] N. Kanzaki, R. M. Giblin-Davis, R. H. Scheffrahn et al., "Reverse taxonomy for elucidating diversity of insect-associated nematodes: a case study with termites," PLoS ONE, vol. 7, no. 8, Article ID e43865, 2012.

[74] T. O. Powers, D. A. Neher, P. Mullin et al., "Tropical nematode diversity: vertical stratification of nematode communities in a Costa Rican humid lowland rainforest," Molecular Ecology, vol. 18, no. 5, pp. 985-996, 2009.

[75] C. Hazir, R. M. Giblin-Davis, N. Keskin et al., "Diversity and distribution of nematodes associated with wild bees in Turkey," Nematology, vol. 12, no. 1, pp. 65-80, 2010.

[76] M. Holterman, S. van den Elsen, H. van Megen et al., "Evolutionary relationships between members of the phylum Nematoda based on small subunit ribosomal DNA sequences," 2004.

[77] N. Kanzaki, H. Kosaka, K. Sayama, J.-I. Takahashi, and S. Makino, "Sphaerularia vespae sp. nov. (Nematoda, Tylenchomorpha, Sphaerularioidea), an endoparasite of a common Japanese hornet, Vespa simillima Smith (Insecta, Hymenoptera, Vespidae)," Zoological Science, vol. 24, no. 11, pp. 1134-1142, 2007.

[78] Q. Yu, "Ditylenchus destructor Thorne, 1945 (Tylenchida: Anguinidae) in Canada," Journal of Nematology, vol. 44, no. 4, pp. 500-500, 2012. 
[79] B. Steven, L. V. Gallegos-Graves, C. Yeager, J. Belnap, and C. R. Kuske, "Common and distinguishing features of the bacterial and fungal communities in biological soil crusts and shrub root zone soils," Soil Biology and Biochemistry, vol. 69, pp. 302-312, 2014.

[80] R. D. L. Oliveira, A. M. Santin, D. J. Seni et al., "Ditylenchus gallaeformans sp. n. (Tylenchida: Anguinidae)-a neotropical gall forming nematode with biocontrol potential against weedy Malastomataceae," Nematology, vol. 15, no. 2, pp. 179-196, 2013.

[81] K. A. Davies, W. Ye, R. M. Giblin-Davis, and K. W. Thomas, "Ficotylus congestae gen. n., sp. n. (Anguinata), from ficus congesta (moraceae) sycones in Australia," Nematology, vol. 11, no. 1, pp. 63-75, 2009.

[82] M. R. Atighi, E. Pourajam, T. J. Pereira et al., "Redescription of Filenchus annulatus (Siddiqui \& Khan, 1983) Siddiqi, 1986 based on specimens from Iran with contributions to the molecular phylogeny of the Tylenchida," Nematology, vol. 15, no. 2, pp. 129141, 2013.

[83] J. E. Palomares-Rius, S. A. Subbotin, G. Liébanas, B. B. Landa, and P. Castillo, "Eutylenchus excretorius Ebsary \& Eveleigh, 1981 Nematoda: Tylodorinae) from Spain with approaches to olecular phylogeny of related genera," Nematology, vol. 11, no. 3, pp. 343-354, 2009.

[84] S. A. Subbotin, E. J. Ragsdale, T. Mullens, P. A. Roberts, M. Mundo-Ocampo, and J. G. Baldwin, "A phylogenetic framework for root lesion nematodes of the genus Pratylenchus (Nematoda): evidence from $18 \mathrm{~S}$ and D2-D3 expansion segments of $28 \mathrm{~S}$ ribosomal RNA genes and morphological characters," Molecular Phylogenetics and Evolution, vol. 48, no. 2, pp. 491505, 2008.

[85] Z. Majd Taheri, Z. Tanha Maafi, S. A. Subbotin, E. Pourjam, and A. Eskandari, "Molecular and phylogenetic studies on Pratylenchidae from Iran with additional data on Pratylenchus delattrei, Pratylenchoides alkani and two unknown species of Hirschmanniella and Pratylenchus," Nematology, vol. 15, pp. 633-651, 2013.

[86] C. Xu, H. Xie, C. Zhao, S. Zhang, and X. Su, "Review of the genus Scutylenchus Jairajpuri, 1971 (Nematoda: Tylenchida), with description of Scutylenchus dongtingensis n. sp. from rhizosphere soil of grass in China," Zootaxa, vol. 3437, pp. 3242.

[87] Y. Yang and S. Zhang, "Identification of Hemicriconemoides gaddi from the Rhizosphere of Longan," Chinese Journal of Tropical Crops, vol. 5, pp. 935-941, 2013.

[88] E. Van den Berg, S. A. Subbotin, and L. R. Tiedt, "Morphological and molecular characterisation of Hemicycliophora lutosa Loof \& Heyns, 1969 and H. typica de Man, 1921 from South Africa (Nematoda: Hemicycliophoridae)," Nematology, vol. 12, no. 2, pp. 303-308, 2010.

[89] N. Vovlas, B. B. Landa, G. Liébanas, Z. A. Handoo, S. A. Subbotin, and P. Castillo, "Characterization of the cystoid nematode Meloidoderita kirjanovae (Nemata: Sphaeronematidae) from Southern Italy," Journal of Nematology, vol. 38, no. 3, pp. 376382, 2006.

[90] J. E. Palomares-Rius, N. Vovlas, S. A. Subbotin et al., "Molecular and morphological characterisation of Sphaeronema alni Turkina \& Chizhov, 1986 (Nematoda: Sphaeronematidae) from Spain compared with a topotype population from Russia," Nematology, vol. 12, no. 4, pp. 649-659, 2010.

[91] G. Liu, J. Chen, S. Xiao, D. Pan, and S. Zhang, "Intraspecific variability of Tylenchulus semipenetrans populations on citrus and Chinese fir," Scientia Agricultura Sinica, vol. 9, 2011.
[92] B. Y. Park, S. N. Park, J. K. Lee, and C. H. Bae, "Morphometric and genetic variability among Tylenchulus semipenetrans populations from citrus growing area in Korea," Plant Pathology Journal, vol. 25, no. 3, pp. 236-240, 2009.

[93] U. Gozel, B. J. Adams, K. B. Nguyen, R. N. Inserra, R. M. GiblinDavis, and L. W. Duncan, "A phylogeny of Belonolaimus populations in Florida inferred from DNA sequences," Nematropica, vol. 36, no. 2, pp. 155-171, 2006.

[94] Z. A. Handoo, A. M. Skantar, and P. Mulrooney, "First report of the sting nematode Belonolaimus longicaudatus on soybean in Delaware," Plant Disease, vol. 94, no. 1, p. 133, 2010.

[95] G. R. Stirling, A. M. Stirling, R. M. Giblin-Davis et al., "Distribution of southern sting nematode, Ibipora lolii (Nematoda: Belonolaimidae), on turfgrass in Australia and its taxonomic relationship to other belonolaimids," Nematology, vol. 15, pp. 401-415, 2013.

[96] J. Parkinson, M. Mitreva, N. Hall, M. Blaxter, and J. P. McCarter, "400000 nematode ESTs on the Net," Trends in Parasitology, vol. 19, no. 7, pp. 283-286, 2003.

[97] D. D. Sui, N. Atibalentja, G. R. Noel, and L. L. Domier, "Genetic diversity of the rDNA locus among 27 populations and 8 races of Heterodera glycines from China, Japan, and the United States, as revealed by PCR-RFLP," Journal of Nematology. In press.

[98] B. Gao, R. Allen, T. Maier, E. L. Davis, T. J. Baum, and R. S. Hussey, "Identification of putative parasitism genes expressed in the esophageal gland cells of the soybean cyst nematode Heterodera glycines," Molecular Plant-Microbe Interactions, vol. 14, no. 10, pp. 1247-1254, 2001.

[99] D. P. Puthoff, M. L. Ehrenfried, B. T. Vinyard, and M. L. Tucker, "GeneChip profiling of transcriptional responses to soybean cyst nematode, Heterodera glycines, colonization of soybean roots," Journal of Experimental Botany, vol. 58, no. 12, pp. 34073418, 2007.

[100] G. E. Múnera Uribe, W. Bert, A. R. Vierstraete, E. de la Peña, M. Moens, and W. Decraemer, "Burrowing nematodes from Colombia and their relationship with Radopholus similis populations, R. arabocoffeae and R. duriophilus," Nematology, vol. 12, pp. 619-629, 2010.

[101] J. Jacob, M. Mitreva, B. Vanholme, and G. Gheysen, "Exploring the transcriptome of the burrowing nematode Radopholus similis," Molecular Genetics and Genomics, vol. 280, no. 1, pp. 117, 2008.

[102] J. Li, D. Peng, and W. Huang, "Phylogentic analysis of Radopholus similis from D2 and D3 fragments of the 28S rRNA gene sequences," Journal of Huazhong Agricultural University, vol. 5, 2008.

[103] S. T. Nyaku, V. R. Sripathi, R. V. Kantety, Y. Q. Gu, K. Lawrence, and G. C. Sharma, "Characterization of the two intra-individual sequence variants in the $18 \mathrm{~S}$ rRNA gene in the plant parasitic nematode, Rotylenchulus reniformis," PLoS ONE, vol. 8, no. 4, Article ID E60891, 2013.

[104] Y. Zhan, A. Matafeo, H. Shi, and J. Zheng, "Morphological and molecular characterization and host range of Rotylenchulus reniformis population occurring in Hangzhou, Zhejiang, China," Acta Phytopathologica Sinica, vol. 41, no. 1, pp. 37-43, 2011.

[105] Y. Zeng, R. M. Giblin-Davis, and W. Ye, "Two new species of Schistonchus (Nematoda: Aphelenchoididae) associated with Ficus hispida in China," Nematology, vol. 9, no. 2, pp. 169-187, 2007.

[106] E. Van Den Berg, S. A. Subbotin, Z. A. Handoo, and L. R. Tiedt, "Hirschmanniella kwazuna sp. n. from South Africa with notes 
on a new record of $H$. spinicaudata (Schuurmans Stekhoven, 1944) Luc \& goodey, 1964 (nematoda: Pratylenchidae) and on the molecular phylogeny of Hirschmanniella Luc \& goodey, 1964," Nematology, vol. 11, no. 4, pp. 523-540, 2009.

[107] C. D. Giorgi, P. Veronico, F. D. Luca, A. Natilla, C. Lanave, and G. Pesole, "Structural and evolutionary analysis of the ribosomal genes of the parasitic nematode Meloidogyne artiellia suggests its ancient origin," Molecular and Biochemical Parasitology, vol. 124, no. 1-2, pp. 91-94, 2002.

[108] G. Anthoine and D. Mugniéry, "Variability of the ITS rDNA and identification of Nacobbus aberrans (Thorne, 1935) Thorne \& Allen, 1944 (Nematoda: Pratylenchidae) by rDNA amplification," Nematology, vol. 7, no. 4, pp. 503-516, 2005.

[109] L. Al-Banna, V. Williamson, and S. L. Gardner, "Phylogenetic analysis of nematodes of the genus Pratylenchus using nuclear 26S rDNA," Molecular Phylogenetics and Evolution, vol. 7, no. 1, pp. 94-102, 1997.

[110] X. Li and J. Zheng, "Identification of four Pratylenchus species based on morphology and PCR-RFLP of rDNA-ITS," Acta Phytopathologica Sinica, vol. 43, no. 4, pp. 444-448, 2013.

[111] M. T. Britton, C. A. Leslie, G. H. McGranahan, and A. M. Dandekar, "Functional genomic analysis of walnut-nematode interactions," Walnut Research Reports 2009, California Walnut Board, 2010.

[112] J. C. Wang, G. M. Huang, Y. D. Wei et al., "Phylogenetic analysis of Pratylenchus (Nematoda: Pratylenchidae based on ribosomal internal transcribed spacers (ITS) and D2/D3 expansion segments of 28S rRNA gene," Acta Zootaxonomica Sinica, vol. 4, pp. 687-693, 2012.

[113] D. Y. Chen, H. F. Ni, and T. T. Tsay, "Identification of a new recorded stunt nematode Tylenchorhynchus zeae (Nematoda: Belonolaimidae) in Taiwan," Plant Pathology Bulletin, vol. 16, no. 2, pp. 79-86, 2007.

[114] J. Liu, R. E. Berry, and A. F. Moldenke, "Phylogenetic relationships of entomopathogenic nematodes (Heterorhabditidae and Steinernematidae) inferred from partial 18S rRNA gene sequences," Journal of Invertebrate Pathology, vol. 69, no. 3, pp. 246-252, 1997.

[115] M. V. Blanco, P. Lax, J. C. Rondan Dueñas, C. N. Gardenal, and M. E. Douc, "Morphological and molecular characterization of the entomoparasitic nematode Hammerschmidtiella diesingi (Nematoda, Oxyurida, Thelastomatidae)," Acta Parasitologica, vol. 57, no. 3, pp. 302-310, 2012.

[116] S. A. Nadler, E. Bolotin, and S. P. Stock, "Phylogenetic relationships of Steinernema Travassos, 1927 (Nematoda: Cephalobina: Steinernematidae) based on nuclear, mitochondrial and morphological data," Systematic Parasitology, vol. 63, no. 3, pp. 161$181,2006$.

[117] O. Douda, M. Zouhar, E. Nováková, J. Mazáková, and P. Ryšánek, "Variability of D2/D3 segment sequences of several populations and pathotypes of potato cyst nematodes (Globodera rostochiensis, Globodera pallida)," Plant Protection Science, vol. 46, no. 4, pp. 171-180, 2010.

[118] S. P. Stock, J. F. Campbell, and S. A. Nadler, "Phylogeny of Steinernema travassos, 1927 (Cephalobina: Steinernematidae) inferred from ribosomal DNA sequences and morphological characters," Journal of Parasitology, vol. 87, no. 4, pp. 877-889, 2001.

[119] E. E. Morris, R. M. Kepler, S. J. Long, D. W. Williams, and A. E. Hajek, "Phylogenetic analysis of Deladenus nematodes parasitizing northeastern North American Sirex species," Journal of Invertebrate Pathology, vol. 113, pp. 177-183, 2013.
[120] Q. Yu, P. de Groot, I. Leal, C. Davis, W. Ye, and B. Foord, “Characterization of Deladenus siricidicola (Tylenchida: Neotylenchidae) ssociated with Sirex noctilio (Hymenoptera: Siricidae) in Canada," Intemational Joumal of Nematology, vol. 19, no. 1, pp. 23-32, 2009.

[121] K. Zhang, H. Liu, J. Sun et al., "Molecular phytogeny of geographical isolates of Bursaphelenchus xylophilus: implications on the origin and spread of this species in China and worldwide," Journal of Nematology, vol. 40, no. 2, pp. 127-137, 2008.

[122] R. B. Gasser and H. Hoste, "Genetic markers for closely-related parasitic nematodes," Molecular and Cellular Probes, vol. 9, no. 5, pp. 315-319, 1995.

[123] T. O. Powers, T. C. Todd, A. M. Burnell et al., "The rDNA internal transcribed spacer region as a taxonomic marker for nematodes," Journal of Nematology, vol. 29, no. 4, pp. 441-450, 1997.

[124] R. Floyd, E. Abebe, A. Papert, and M. Blaxter, "Molecular barcodes for soil nematode identification," Molecular Ecology, vol. 11, no. 4, pp. 839-850, 2002.

[125] A. Eyualem and M. Blaxter, "Comparison of biological, molecular, and morphological methods of species identification in a set of cultured Panagrolaimus isolates," Journal of Nematology, vol. 35, no. 1, pp. 119-128, 2003.

[126] P. De Ley, I. T. De Ley, K. Morris et al., "An integrated approach to fast and informative morphological vouchering of nematodes for applications in molecular barcoding," Philosophical Transactions of the Royal Society B, vol. 360, no. 1462, pp. 1945-1958, 2005.

[127] N. R. R. Da Silva, M. C. Da Silva, V. F. Genevois et al., "Marine nematode taxonomy in the age of DNA: the present and future of molecular tools to assess their biodiversity," Nematology, vol. 12, no. 5, pp. 661-672, 2010.

[128] M. A. Smith, D. M. Wood, D. H. Janzen, W. Hallwachs, and P. D. N. Hebert, "DNA barcodes affirm that 16 species of apparently generalist tropical parasitoid flies (Diptera, Tachinidae) are not all generalists," Proceedings of the National Academy of Sciences of the United States of America, vol. 104, no. 12, pp. 4967-4972, 2007.

[129] H. van Megen, S. van den Elsen, M. Holterman et al., "A phylogenetic tree of nematodes based on about 1200 full-length small subunit ribosomal DNA sequences," Nematology, vol. 11, no. 6, pp. 927-950, 2009.

[130] A. Yu. Ryss, "Phylogeny of the order Tylenchida (Nematoda)," Russian Journal of Nematology, vol. 1, no. 2, pp. 74-95, 1993.

[131] L. K. Carta, A. M. Skantar, and Z. A. Handoo, "Molecular rDNA phylogeny of telotylenchidae siddiqi, 1960 and evaluation of tail termini," Journal of Nematology, vol. 42, no. 4, pp. 359-369, 2010.

[132] R. A. Bedding, "Controlling the pine-killing woodwasp, Sirex noctilio, with nematodes," in Use of Microbes For Control of Invasive Arthropods, A. E. Hajek, T. R. Glare, and M. O'Callaghan, Eds., pp. 213-235, Springer, Amsterdam, The Netherlands, 2009.

[133] A. R. Maggenti, M. Luc, D. J. Raski, R. Fortuner, and E. Geraert, "A reappraisal of Tylenchina (Nemata). 2. Classification of the suborder Tylenchina (Nemata: Diplogasteria)," Revue De Nématologie, vol. 10, no. 2, pp. 135-142, 1987.

[134] V. N. Chizhov and S. N. Kruchina, "Phylogeny of the nematode order Tylenchida (Nematoda)," Zoologichesky Zhurnal, vol. 67, no. 9, pp. 1282-1293, 1988.

[135] M. Luc, A. R. Maggenti, R. Fortuner, D. J. Raski, and E. Geraert, "A Reappraisal of Tylenchina (Nemata) 1. For a New Approach to the Taxonomy of Tylenchina," Revue De Nématologie, vol. 10, no. 2, pp. 127-134, 1987. 
[136] O. V. Slobodyanyuk, "Host specificity in tylenchids of fleas," in Abstracts of Papers Presented at the Russian Society of Nematologists 1st English Language International Symposium, pp. 102-103, Zoological Institute of the Russian Academy of Sciences, 1995.

[137] K. D. Elsey, "Parasitism of some economically important species of chrysomelidae by nematodes of the genus howardula," Journal of Invertebrate Pathology, vol. 29, no. 3, pp. 384-385, 1977.

[138] G. O. Poinar Jr., J. Jaenike, and D. D. Shoemaker, "Howardula neocosmis sp.n. parasitizing North American Drosophila (Diptera: Drosophilidae) with a listing of the species of Howardula Cobb, 1921 (Tylenchida: Allantonematidae)," Fundamental and Applied Nematology, vol. 21, no. 5, pp. 547-552, 1998.

[139] R. L. H. Dennis, L. Dapporto, S. Fattorini, and L. M. Cook, "The generalism-specialism debate: the role of generalists in the life and death of species," Biological Journal of the Linnean Society, vol. 104, pp. 725-737, 2011.

[140] C. E. Richmond, D. L. Breitburg, and K. A. Rose, "The role of environmental generalist species in ecosystem function," Ecological Modelling, vol. 188, no. 2-4, pp. 279-295, 2005.

[141] M. E. J. Woolhouse, L. H. Taylor, and D. T. Haydon, "Population biology of multihost pathogens," Science, vol. 292, no. 5519, pp. 1109-1112, 2001.

[142] H. D. Loxdale, G. Lushai, and J. A. Harvey, "The evolutionary improbability of "generalism" in nature, with special reference to insects," Biological Journal of the Linnean Society, vol. 103, no. 1, pp. 1-18, 2011.

[143] J. C. Castillo, S. E. Reynolds, and I. Eleftherianos, "Insect immune responses to nematode parasites," Trends in Parasitology, vol. 27, no. 12, pp. 537-547, 2011.

[144] R. Kassen, “The experimental evolution of specialists, generalists, and the maintenance of diversity," Journal of Evolutionary Biology, vol. 15, no. 2, pp. 173-190, 2002.

[145] N. I. Samia, K. L. Kausrud, H. Heesterbeek et al., "Dynamics of the plague-wildlife-human system in Central Asia are controlled by two epidemiological thresholds," Proceedings of the National Academy of Sciences of the United States of America, vol. 108, no. 35, pp. 14527-14532, 2011.

[146] H. E. Kaiser and A. J. Boucot, "Specialisation and extinction: cope's law revisited," Historical Biology, vol. 11, no. 1-4, pp. 247265, 1996.

[147] C. Darby, A. Chakraborti, S. M. Politz, C. C. Daniels, L. Tan, and K. Drace, "Caenorhabditis elegans mutants resistant to attachment of Yersinia biofilms," Genetics, vol. 176, no. 1, pp. 221230, 2007.

[148] G. A. Eroshenko, N. A. Vidyaeva, and V. V. Kutyrev, "Comparative analysis of biofilm formation by main and nonmain subspecies Yersinia pestis strains," FEMS Immunology and Medical Microbiology, vol. 59, no. 3, pp. 513-520, 2010.

[149] G. A. Eroshenko, N. A. Vidyaeva, L. M. Kukleva et al., "Studies of biofilm formation in non-pigmented and plasmid-deprived mutants of Yersinia pestis on biotic surfaces, in vivo and in vitro conditions," Problems of Particularliy Dangerous Infections, vol. 113, pp. 45-49, 2012. 

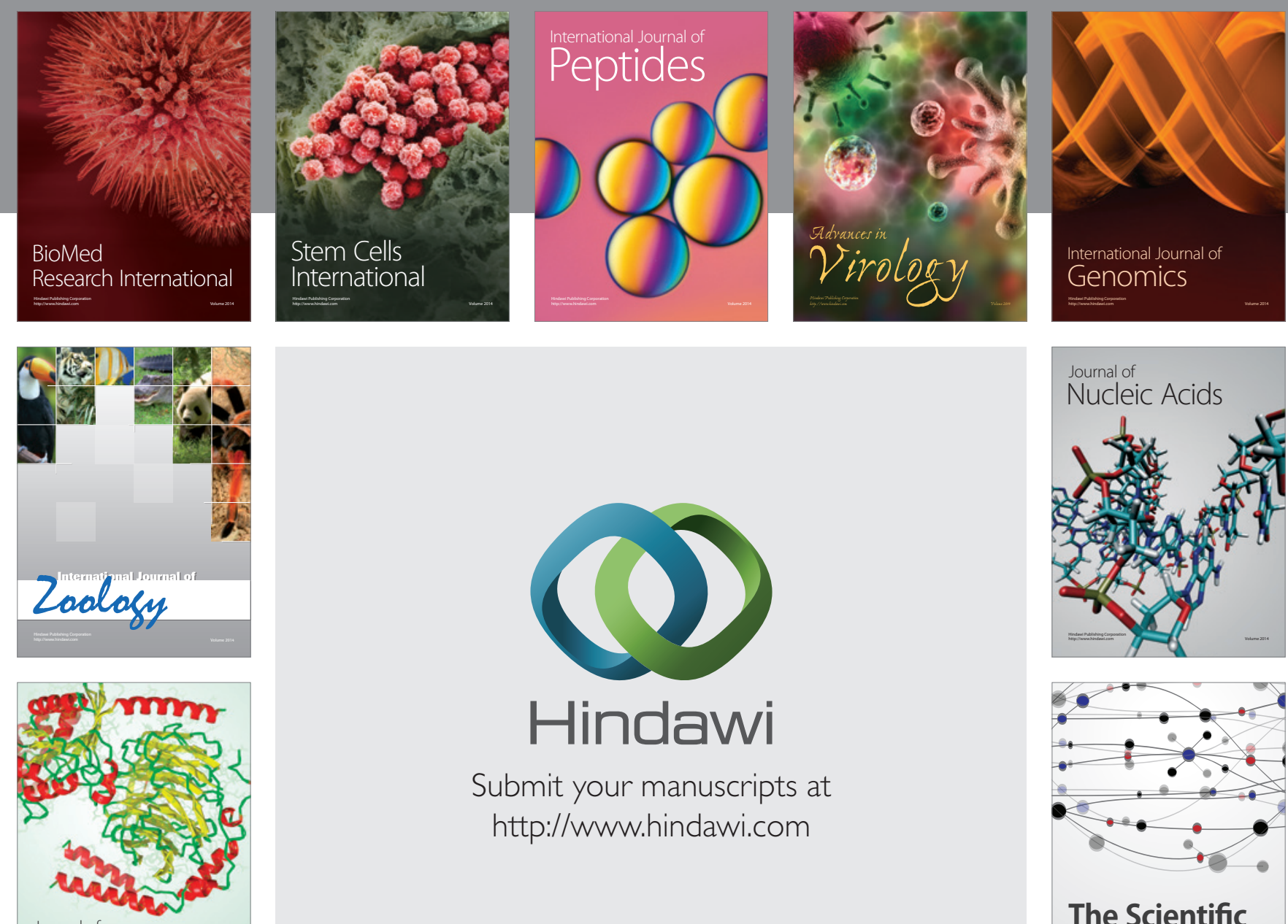

Submit your manuscripts at

http://www.hindawi.com

Journal of
Signal Transduction
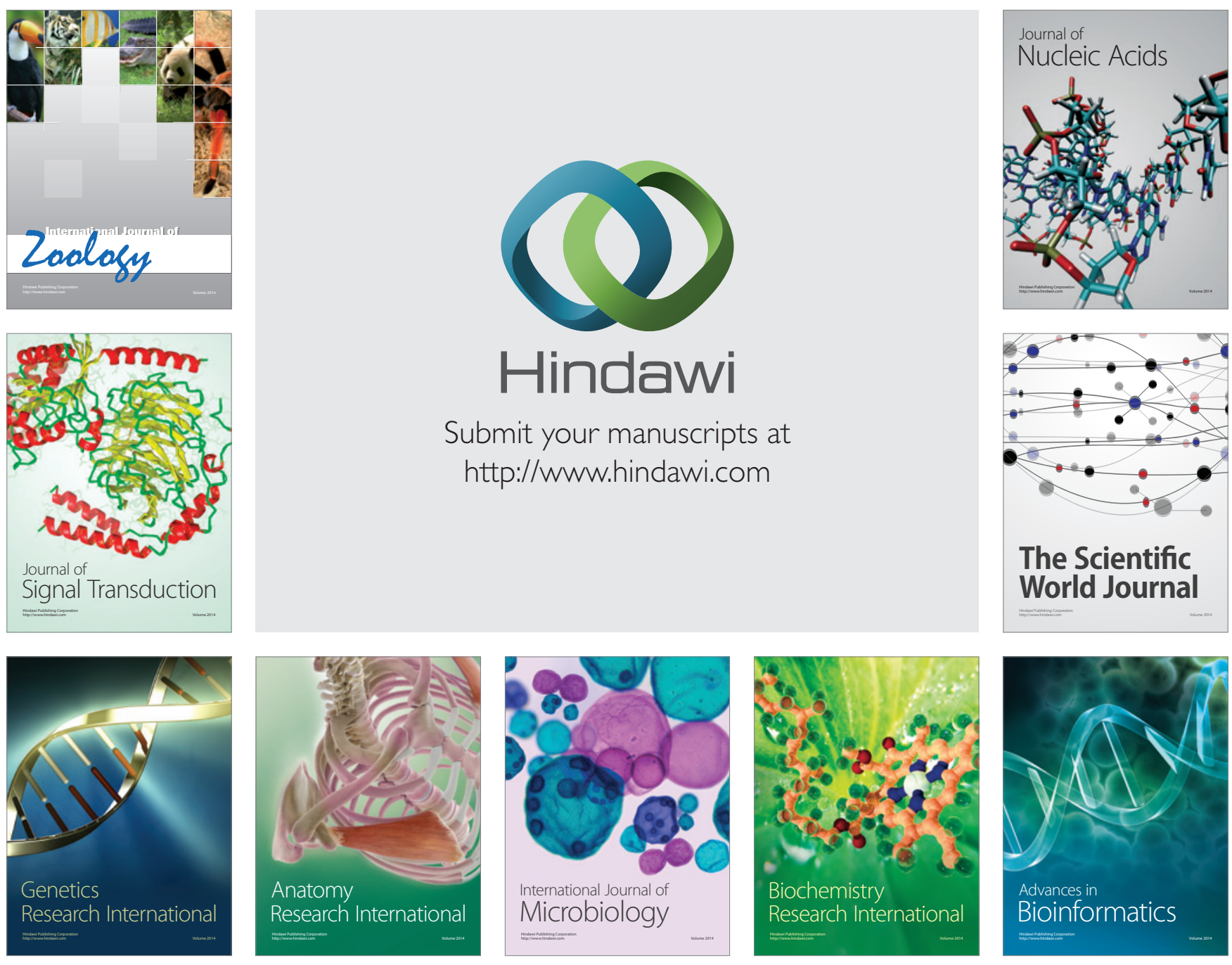

The Scientific World Journal
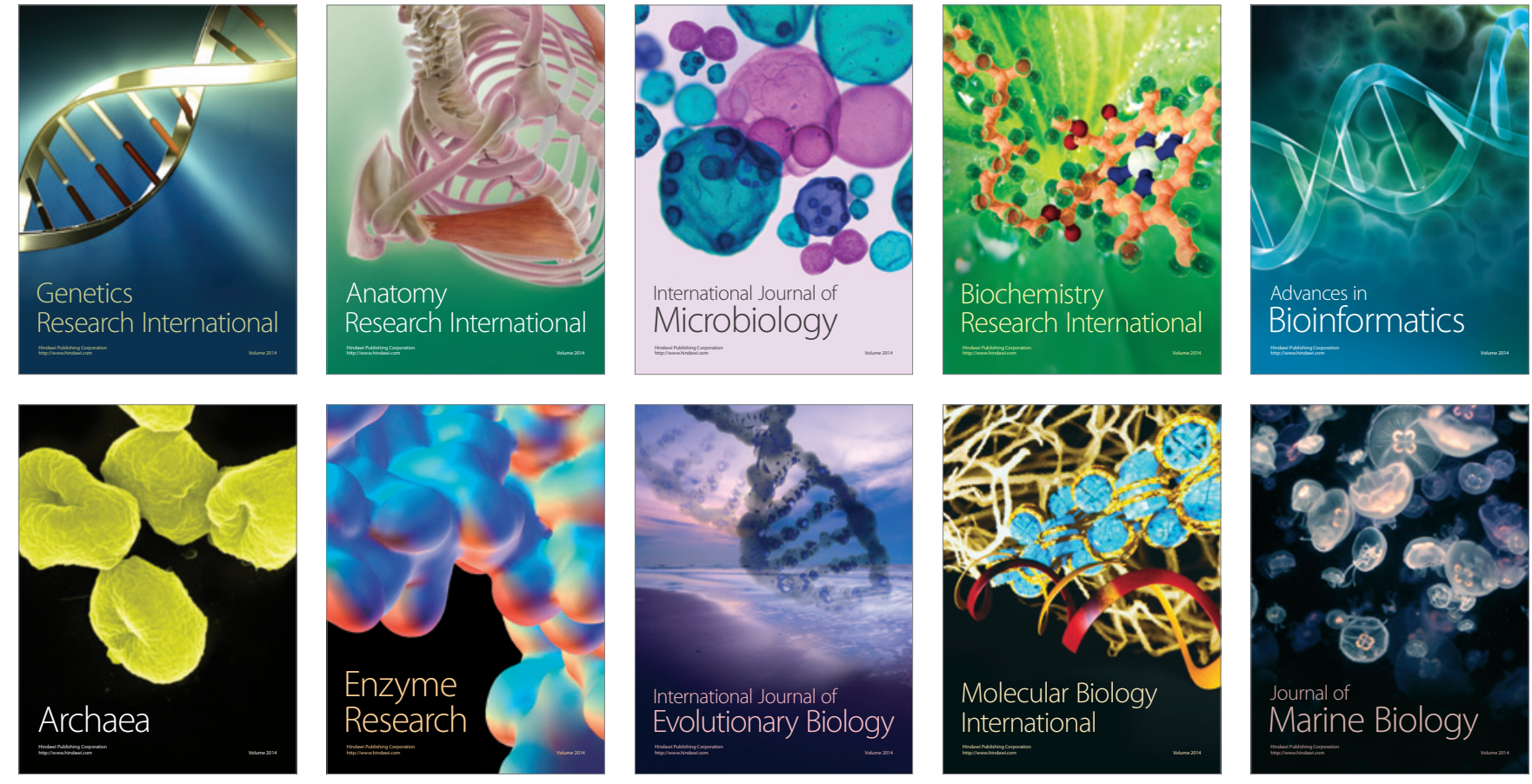